\title{
Challenges and Barriers to the Interaction of High Councils of Health with the Ministry of Health and Medical Education in Iran: A Qualitative Study
}

\author{
Amin Karimi $^{1}$ (D) Soad Mahfoozpour $^{2 *}$ iD , Somayeh Hesam ${ }^{1}$, Behzad Damari $^{3}$ \\ ${ }^{1}$ Dept of Health Services Management, Faculty of Management, Islamic Azad University, South Tehran Branch, Tehran, Iran \\ ${ }^{2}$ Dept of Health Services Management, Shahid Beheshti University of Medical Sciences, Tehran, Iran \\ ${ }^{3}$ Dept of Social Health Components, National Tehran University of Medical Sciences, Tehran, Iran
}

Article Info A B S T R A C T

Article type:

Research article

\section{Article History:}

Received: 06 October 2020

Revised: 01 December 2021

Accepted: 19 June 2021

\section{* Correspondence to:}

Soad Mahfoozpour

Dept of Health Services

Management, Shahid Beheshti

University of Medical Sciences,

Tehran, Iran

Email:

smahfoozpour@gmail.com
Introduction: The Ministry of Health influences the executive organizations through the high councils and the decision-making system. It is necessary to adopt an inter-sectoral cooperation approach, seek appropriate support for interacting with these councils, focus on the health taken decisions, and analyze their current situation. This study aimed to investigate the challenges and barriers to the interaction of high councils of health with the Iran Ministry of Health.

Material \& Methods: The present study is a field-based qualitative study that was conducted to analyze the current situation of the High Councils. Data were collected through interviews, group discussion sessions, and document analysis. To collect the data, 23 interviews and 2 focus group sessions were conducted using purposive sampling. The obtained data were then analyzed using MAXQDA software (version 10).

(Ethic code: 162432750)

Findings: The results of the study showed that in terms of activity, the elected high councils are divided into three categories of active, semi-active, and inactive. Challenges facing these councils include lack of financial and human resources, inadequate structure and organization, non-transparent rules and regulations, lack of executive guarantees, poor planning and cross-sectoral coordination, lack of monitoring and evaluation system, low level of awareness and attitude of policy makers and managers about health, poor leadership of the Ministry of Health, and finally the lack of a health appendix in approvals. The improvement of the performance of high councils in applying the health appendix to approvals can be achieved through such interventions as 1. Policy interventions, 2. Executive structure interventions, and 3. Culture building and advocacy.

Discussion \& Conclusion: According to the results of the study, it is necessary for the health system to develop inter-sectoral cooperation and seek appropriate support from high councils in order to fairly improve community health indicators, take action to reduce barriers to interaction through policy, executive, culturebuilding, and advocacy interventions.

Keywords: Advocacy, Cross-sectoral cooperation, High councils

$>$ How to cite this paper

Karimi A, Mahfoozpour S, Hesam S, Damari B. Challenges and Barriers to the Interaction of High Councils of Health with the Ministry of Health and Medical Education in Iran: A Qualitative Study. Journal of Ilam University of Medical Sciences. November 2021;29(4): 28-45. 


\title{
بررسى حالشها و موانع تعامل شوراهاى عالى مؤثر بر سلامت با وزارت بهداشت، درمان و آموزش يز شكى در ايران: يك مطالعد كيفى
}

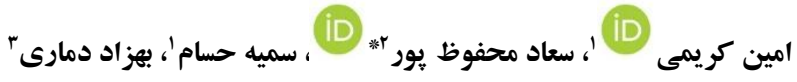

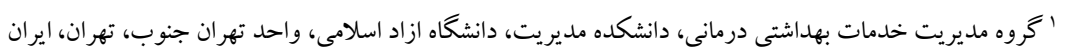

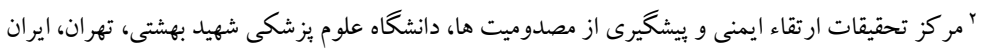

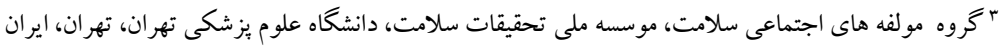

اطلاعات مقاله

مقدمه: وزارت بهداشـت از طريق شـو راهاى عالى و نظام تصـميم گيرى بر دسـخاههاى اجرايى تأثير مى گذارد. به منظور

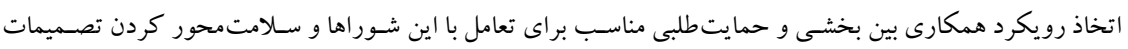

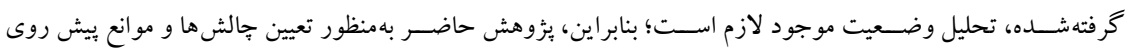

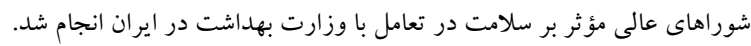

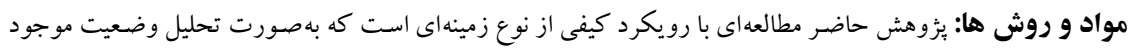

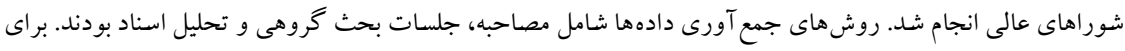

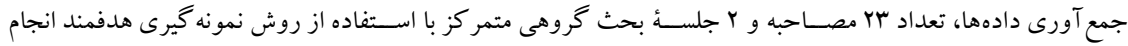

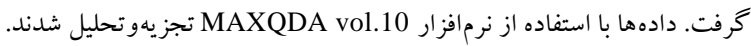

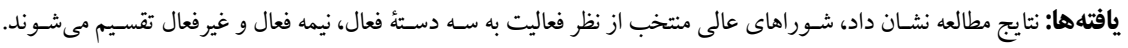

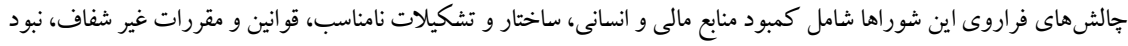

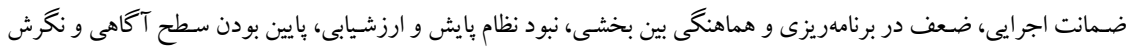

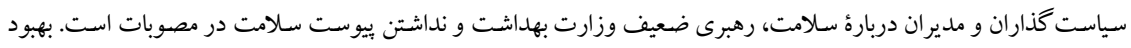

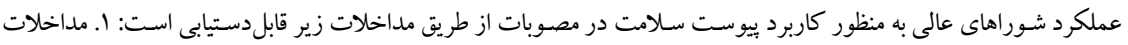

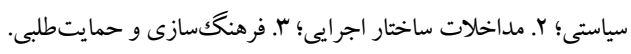

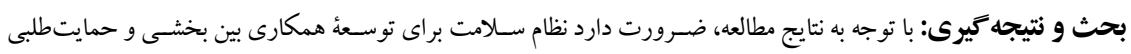

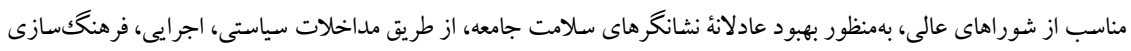
و حمايت طلبى نسبت به كاهش موانع تعامل اقدام كند.
نوع مقاله: يُزوهشى

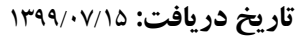
تاريخ داورى:

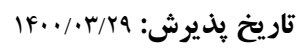

$$
\text { نويسنده مسئول: }
$$
مركز تحقيقات ارتقاء ايمنى و و سحطور يشيخيرى از مصدوميت ها، دانشكاه علوم يزشكى شهيد بهشتى، تهران،

ايران

Email:

smahfoozpour@gmail.com

وازههاى كليدى: حمايت طلبى، شوراهاى عالى، همكارى بين بخشى

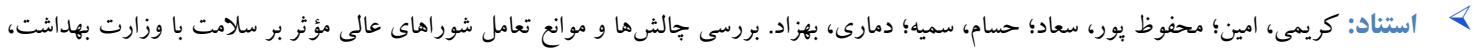

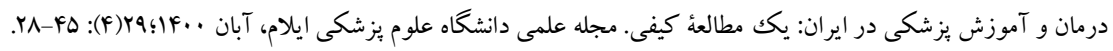


تأثيرات احتمالى سياستهاى آنها بر سلامت، بهويزه بر سلامت آسيب يذيرترين گروهها در اجتماع ارزيابى شود؛

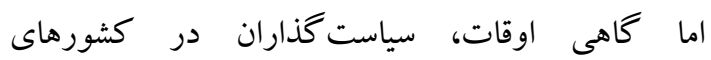
درحالتوسعه دركى كه از سلامت دارند، عمدتاً در حد توجه به خدمات يزشكى است؛ بنابراين، ارتباط بسيارى ميان مسئوليتهاى خود و سلامت نمىيابند. اين وظيفه بخش سلامت است كه آنان را آكاه كند (ه). نگًاهى به بيشينه استقرار و تشكيلات همكارى بين بخشى براى

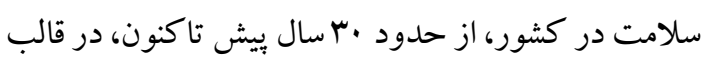
شوراهاى فرابخشى مختلف در كشور نشان مىدهد كه زمينه ساختارى و شبكهاى لازم براى كاربست مؤثر تكنيككا و روشهاى حمايتطلبى براى سلامت، ازجمله توليد و استفاده از شواهد، ائتلافسازى، استفاده از رسانه هاى اجتماعى، يايش روند اجراى سياستها،

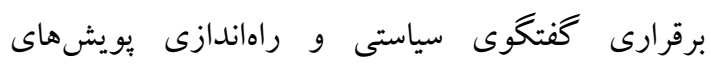
حمايتطلبى بهخوبى وجود داشته و بهعنوان يكك ابزار كليدى از آن استفادهشده است (4). شوراهاى عالى ادارى كه مطابق قوانين و مقررات بيش و يس از انقلاب ايجادشدهاند، دامنهُ وسيعى از شوراهاى موجود در نظام حقوقى كشورمان را تشكيل مىدهند و تأثير فراوانى در نظام تصميم گيرى در سازمانهاى ادارى دارند. در تعريف شوراهاى عالى ادارى مىتوان بيان داشت كه اينها شوراهايى هستند كه در درون قوهُ مجريه و در كنار سازمانهاى ادارى مركزى و دستخاههاى اجرايى مركزى زير نظر قوهُ مجريه تشكيل مىشوند (V). مجموعهاى از شوراهاى عالى كه عملاً تحت رياست رئيس قوهُ مجريه هستند و دبيرخانهاى آنها و مراكز تحقيقات راهبردى مربوطه كه مسئوليت تصميم گيرىهاى راهبردى اعم از

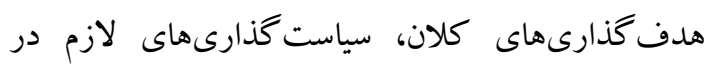
عرصهاى مختلف و نظارت و ارزيابى راهبردى رادارند، ردهُ مديريت راهبردى كشور را تشكيل مىدهند (V). با وجود اين، تلاش بهمنظور نظمدهى و سازمان بخشيدن به

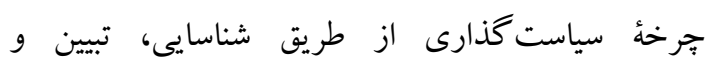

در دنياى امروز، ديدگاههاى سلامت جشماندازى وسيع ترى بيدا كرده و ضرورتاً به عوامل تعيين كننده غير طبى سلامت توجه ويزواى معطوف شده است. هريك از اين تعيين كنندهها بهخودىخود و يا از طريق تأثير بر يكديگر وضعيت سلامتى را بهشدت تحت تأثير قرار مىدهند و سبب بروز بىعدالتىهايى در وضعيت سلامت

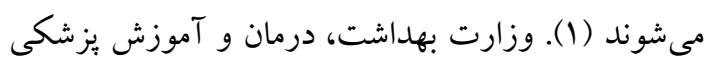
بهعنوان متولى اصلى تأمين و حفظ سلامت مردم كشور، با هدف رسيدن به بالاترين سطح ممكن سلامتى براى آحاد

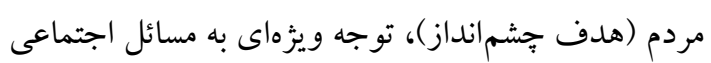
تأثير گذار بر سلامت و موضوع عدالت در سلامت داشته است؛ اما حفظ و ارتقاى سلامت و حذف اثر مخرب برخى از تعيين كنندهاى اجتماعى مؤثر بر سلامت مسئوليتى فردى، كشورى و حتى بينالمللى است كه كوشش مشترك همة سطوح جامعه يعنى افراد و سازمانها را

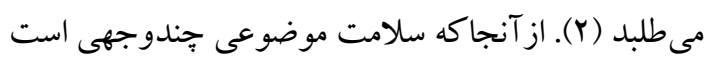
و دستيابى يكك جامعه به آن نيازمند به كار گيرى روشهايى سيى است كه به مشاركت و همكارى بين بخشى منجر مى شود، نخاهى به تعيين كندههاى اجتماعى سلامت مشخص مىسازد كه تأمين، حفظ و ارتقاى سلامت يكك جامعه از طريق يكك وزارتخانه (بهداشت) ممكن نخواهد شد (r). امروزه، سلامت بهعنوان محصول مشتر كك همؤ بخشهاى توسعه و همكارى بين بخشى، مهم ترين راهبرد تحقق آن شناخته مى شود. حمايت طلبى يكى از ابزارهاى مهم استقرار توليت و از بيشرانهاى اصلى جلب نظر ذىنفعان و توسعُ همكارى بين بخشى در نظام سلامت است. حمايت طلبى براى سلامت با هدف قرار دادن سلامت در فهرست موضوعات اولويتدار دستور كار همهُ بخشهاى توسعه در بيانية آدلايد (19MA)، بهعنوان يكى از F حيطه براى اقدام، بهمنظور تدوين سياستهاى عمومى سالم بر آن تأكيد شده است (F). بيشتر عوامل ايجاد كنندة نابر ابرى در سلامت در بخشهاى مختلف اجتماعى يراكنده هستند. بايد در سياست گذارىها رويكرد فرابخشى داشت و 
تبيين وضعيت موجود شور/هاى عالى مؤثر بر سلامت:

براى بررسى وضعيت موجود شوراهاى عالى مؤثر بر سلامت، از مطالعهُ منابع و متون، اسناد بالادستى و و سايتهاى اينترنتى، مصوبات و مقررات شوراهاى عالى ماتى ماتح

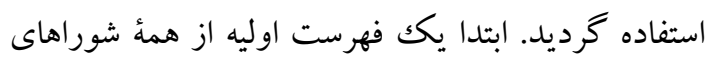
عالى با رجوع به سايتهاى اينترنتى داخلى شامل بايگاه اطلاعرسانى دولت (·)، مركز اسناد و مداركك علمى وابسته به وزارت فرهنگ و آموزش عالى (11)، بزخوهش انجامشده از سوى كيانى، خانجانخانى، شيروانى و احمدى

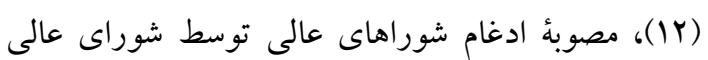
ادارى (r) تهيه شد. درمجموع، حدود شصت شوراى عالى با عناوين شورا، ستاد و... احصاء گرديد كه در كشور وجود دارد؛ سيس با استفاده از نظر گروه يزوهش و و كارشناسان دبيرخانهُ شوراى عالى سلامت و امنيت غذايى، ه شوراى عالى كه مصوبات آنها بر سلامت اثر خذار است، انتخاب و از طريق دبيرخانهُ شوراى عالى سلامت نسبت به معرفى يزوهشخر براى انجام مصاحبه اقدام گرديد. q شورا تمايلى به همكارى نداشتند كه عبارت بودند از:

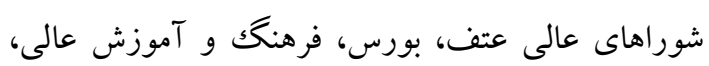
انقلاب فرهنگى، امنيت ملى، اشتغال، آب، يول و اعتبار،

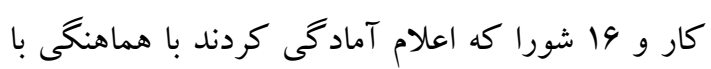
دبيرخانه آنها، مقدمات انجام مصاحبه فراهم شد. يس از هماهنكى و انجام مصاحبه با دبير يا كارشناسان دبيرخانهُ شوراهاى منتخب مشخص گرديد كه اين شوراها از نظر وضعيت فعاليت و ييخيرى اهداف (تشكيل جلسات و توليد مصوبات) متفاوت هستند و به سه دسته فعال، نيمه فعال و

$$
\text { غيرفعال تقسيم گرديدند (جدول شمارة ()). }
$$
ابزار و روش كردآورى دادهها: براى گردآورى و

تكميل دادههاى موردنياز، ززارش عملكرد سالانه شوراهاى عالى منتخب، اسناد، كتاب قانون، خطمشىها، آيين نامها و ساير اسناد مرتبط مطالعه شد؛ همجنين اطلاعات تكميلى در زمينه روند تغييرات مقررات هر شورا، تعداد مصوبات مرتبط با سلامت، تعداد جلسات ساليانه، وضعيت اجرايى شدن مصوبات، وضعيت حضور اعضاى
مشروعيتبخشى به مراحل جرخه، متناسب با شرايط محيطى و مقتضيات حاكم، بهويثه در سطح سياستهاى اجرايى و تدبيرى مىتواند گام مؤثرى براى استقرار و

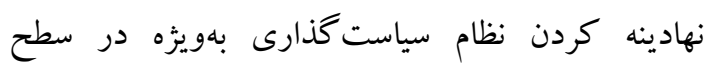
فرابخشى سلامت بهشمار آيد (1). با عنايت به نقش و جايگاه شوراهاى عالى در نظام تصميم گيرى كشور و تأثيرى كه مى توانند بر سلامت جامعه داشته باشند، تعامل و همراهى نظام سلامت با اين شوراها اهميت بالايى دارد؛ بنابر اين مى طلبد كه سياست گذاران حوزهُ سلامت به آن توجه كنند. در كشور ما و ديخر كشورهاى درحالتوسعه، تاكنون مطالعهاى بيرامون شوراهاى عالى مؤثر بر سلامت

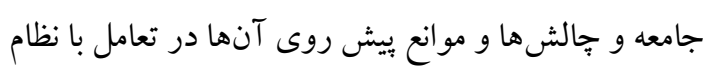
سلامت، بهمنظور كنترل عوامل تهديد كننده و بهبود نشانگرهاى سلامت انجامنشده است؛ به همين سبب، يُزوهش حاضر بهمنظور تعيين جالشها و موانع بيش روى شوراهاى عالى مؤثر بر سلامت در تعامل باوزارت بهداشت

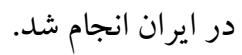

\section{مواد و روش ها}

اين بثروشش، مطالعهاى كيفى به روش كراندد تئورى است. گر اندد تئورى نظريهاى است كه از طريق جمع آورى سامانمند دادهها و تحليل اطلاعات مربوط به يديده كشفشده، توسعه يافته و بهطور مشروط و موقت تائيد شده است. محقق كار خود را با يكك تئورى شروع نمى كند كه بخو اهد آن را اثبات نمايد، بلكه با يكك مطالعه در عرصه آغاز مى كند و اجازه مىدهد كه جيزهايى كه به آن عرصه مربوط مىشوند، خود را نمايان سازند؛ ازاينرو، جمع آورى دادهها، تحليل و تئورى با يكديخر رابطه دوطرفه دارند. هدف محقق آن است كه از لحاظ نظرى به توضيح كامل درباره يكك يديدة خاص برسد (9). جامعه يثزوهش، دبيران و كارشناسان خبرهُ دبيرخانهُ شوراهاى عالى هستند. افراد مصاحبهشونده بر اساس معيارهايى مانند داشتن تجربؤ مرتبط، تحصيلات، سابقهُ مسئوليت در شورا و عضويت در كروهها و كميتههاى مرتبط انتخاب شدند. 
جدول 1. وضعيت شوراهاى عالى از نظر فعاليت

\begin{tabular}{|c|c|c|}
\hline تعداد & نام شوراهاى عالى & فعاليت \\
\hline 9 & 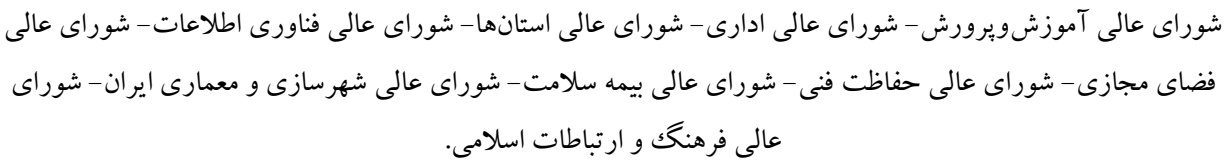 & فعال \\
\hline r & شوراى عالى جو انان- شوراى عالى فضايى - شوراى عالى حفاظت از محيطزيست. & نيمه فعال \\
\hline F & شوراى عالى اسباببازى - شوراى عالى ورزش - شوراى عالى رفاه و تأمين اجتماعى - شوراى عالى مبارزه با جرائم & غير فعال \\
\hline 19 & & جمع كل \\
\hline
\end{tabular}

مصوبات شوراى عالى بر مقوله سلامت است؟ ؟ُ. جهه الزاماتى براى تقويت نقش و عملكرد شوراى عالى در موضوعات سلامت بيشنهاد مى كنيد؟ ه. انتظار شما از دبيرخانه شوراى عالى سلامت و امنيت غذايى و درمجموع وزارت بهداشت، براى تعامل با شوراى عالى شما جِيست؟

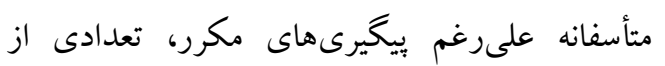
دبير خانه شور اها حاضر به همكارى نشدند (9 شوراى عالى) كه ناجار با بررسى مجدد، شور اهاى جديدى به ليست اوليه

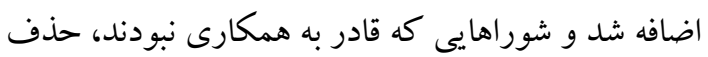

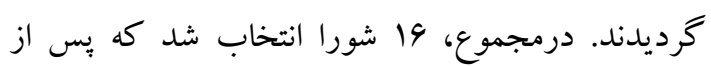
تكميل ليست با هماهنكى دبيرخانه شوراهاى منتخب، افر ادى كه شناختهشده بودند بهصورت هدفمند براى انجام مصاحبه انتخاب كرديدند. در طول مصاحبههاى اوليه، از طريق نمونه گيرى گلوله برفى و با نظرخواهى از افراد مصاحبه شونده و همجينين اطلاعاتى كه از تحليل مصاحبهها و تحليل اسناد بهدست آمد، ساير ذىنفعان و افراد صاحبنظر در دبيرخانه هر شورا شناسايى و به نمونهُ اوليه اضافه شد، بدين ترتيب كه بس از هر مصاحبه، جنانجه خود مصاحبه شونده فرد مطلع ديخرى رادر حوزهُ مطالعه معرفى نه مى كرد، با آن فرد نيز براى مصاحبه هماهنگك مىشد؛ يا بهورت فعال از مصاحبهشوندهها درخواست مى گرديد تا جنانجه افراد ديخرى در دبيرخانه شورا و خود شوراى مدنظر سراغ داشتند، آنان را معرفى كنند. شوراهاى عالى و تعداد مصاحبهشوند گان: شوراى عالى ادارى (Y) - شوراى عالى رفاه و تأمين اجتماعى (Y) - شوراى عالى آموزشويرورش (Y) - شوراى
اصلى در جلسات، وضعيت دبيرخانه و نظام كارى آن، تعداد و تركيب اعضاى هر شورا، تعداد جلسات تشكيل دادهشد، تعداد مصوبات مربوط به سلامت، ميزان تفاهم نامهاى تدوينشده دربارهُ سلامت، روند بيگيرى مصوبات و عو امل مؤثر بر عملكرد اين شوراها و موانع و جالشهاى بيش روى آنها مانند ساختار و تشكيلات دبيرخانه، منابع و اعتبارات و نيروى انسانى موردنياز، ضمانت اجرايى مصوبات، عزم و ارادهُ ملى، يِيوست سلامت در مصوبات، دانش و آكاهى سياست گذاران در زمينهُ سلامت، وجود قوانين و مقررات موازى، فقدان برنامههاى مؤثر، فقدان نظام نظارت، يايش و ارزشيابى در اجراى مصوبات در محيط از طريق فرم اطلاعاتى طر احىشده از سوى بثزوهشخر و مصاحبه هاى عمقى فردى با مسئولين و كارشناسان مطلع و صاحبنظران مربوطه در دبيرخانه شور اهاى عالى منتخب (r مصاحبه) با استفاده از راهنماى مصاحبة كيفى نيمهساختاريافته جمع آورى كرديد. يرسشها بر اساس اهداف مطالعه، مصاحبة مقدماتى با جند تن از كارشناسان خبره در حوزهُ برون و درون بخش سلامت و با مطالعه مقالات داخلى و خارجى و نظر اعضاى گروه بثوهش تدوين شد. سؤالات يرسش نامه به شرح زير بودند:

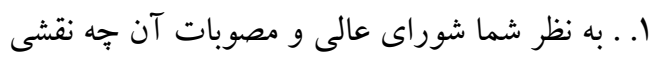
در سلامت مردم مى تواند داشته باشند؟ r. كدام عوامل مى توانند بر نقش و عملكرد اين شورا بهصورت مستقيم و غيرمستقيم در ارتقاى سلامت مردم مؤثر باشند؟ س. به نظر شما جهه جالشها و مشكلاتى در حال حاضر مانع تأثير 
از مراجعهُ آنان به محل، با ارائٔ توضيحاتى در مواردى

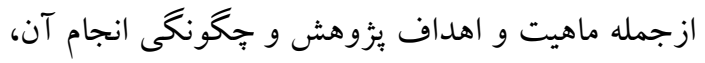

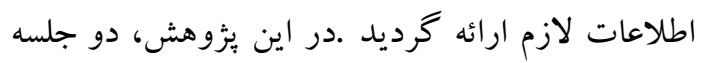
بحث گروهى به مدت يككونيم و يكك ساعت بر گزار شد آدأ كه طى اين جلسات، شركت كنند كان آزادانه اظهار

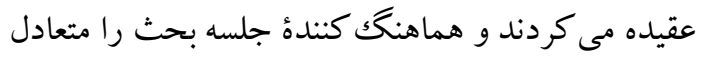

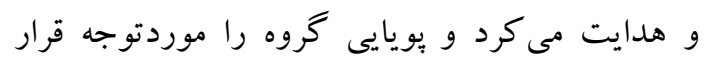

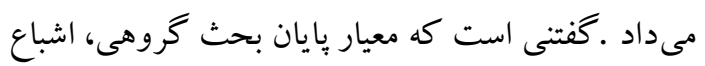

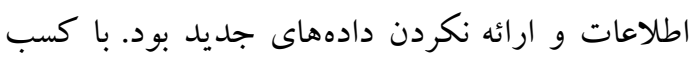
اجازه از مصاحبهشوندگان و اطمينان دادن به آنان

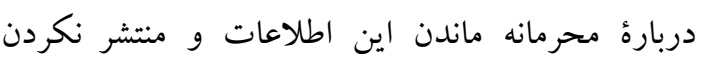
آنها، جداكانه و به تفكيك نام مشاركت كنند كان، مصاحبهها ضبط گرديد .حين ضبط مكالمات، از از يادداشتبردارى نيز استفاده شد. به علت فاصلة متفاوت افراد از ضبط و وجود صداهاى مختلف، يياده كردن Voice نوارها دشوار بود و براى حل اين مشكل Recorder

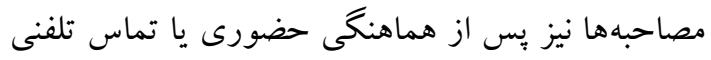
با افراد مدنظر، وقت ملاقات تعيين مى گرديد. در ارتباط با مكان مصاحبه نيز جايى انتخاب مىشد كه مصاحبه كنند كان در آن مكان احساس راحتى كنند . كفتنى است كه مصاحبهها در زمان و محل تعيين شده و و از سوى يزوهشخر صورت كرفت. يِيش از شروع

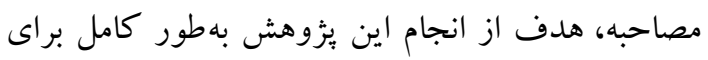

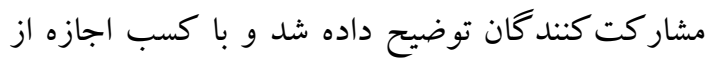
مصاحبهشوند كان و اطمينان دادن به آنان دربارهٔ محرمانه ماندن اطلاعات، مصاحبهها ضبط گرديد. علاوه بر اين، حين بحث گروهى و مصاحبه، مواردى همجِون كنترل

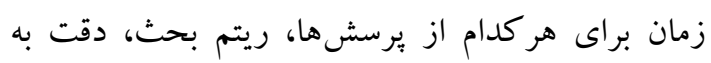
ارتباطات غيرشفاهى و نيز بيان خلاصهاى از موارد ذكرشده در جلسه براى كمك به به تحليل اطلاعات بـات

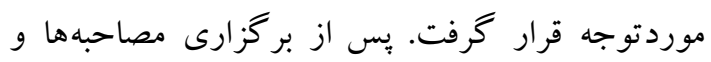

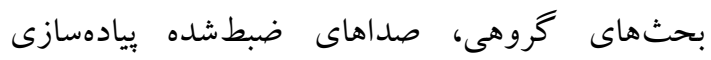
كرديد و نوشتن متن نوارها در نزديككت ترين فاصلهُ زمانى

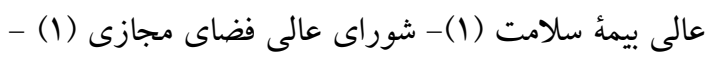

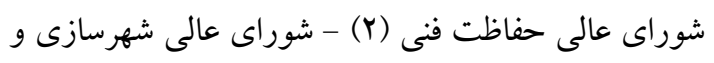

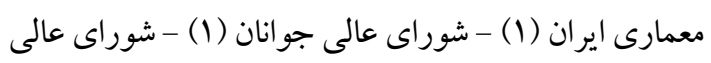

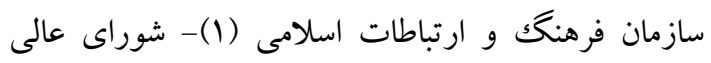
حفاظت محيطزيست (1)- شوراى عالى فضايى (1)-

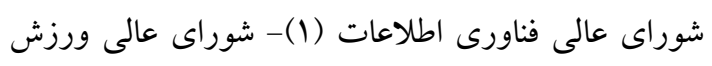

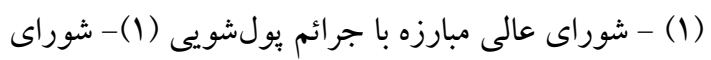
عالى اسباببازى (Y)- شوراى عالى استانها (Y). تعداد كل

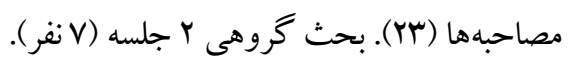
تحليل دادهها: در اين مطالعه، براى تحليل دادهها از

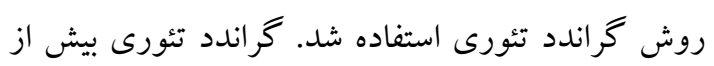
آنجه روش تحقيق باشد، روشى براى تحليل دادههاست.

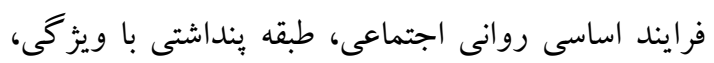

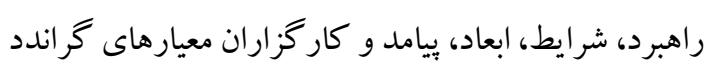

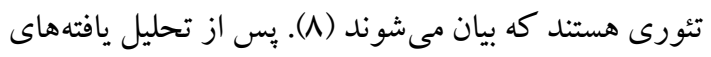

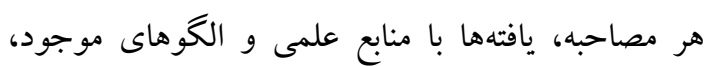

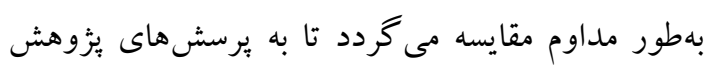

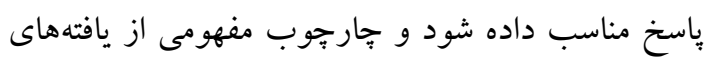
مطالعه حاصل گردد. براى ارزيابى كيفيت كار، از جهار ويزگى قابل اعتبار بودن، قابل انتقال بودن، قابل اطمينان بودن و قابل تائيد بودن لينكلن و گوبا استفاده شد. به منظور

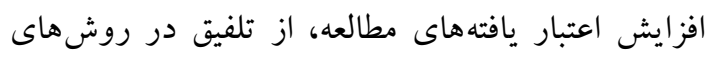
گردآورى اطلاعات (مصاحبه، بحث گروهى، تحليل

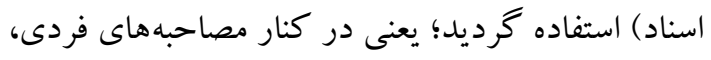
از جلسات بحث گروهى و تحليل اسناد شامل خبرها،

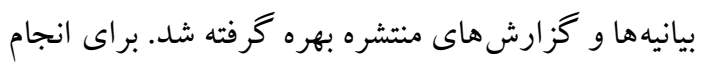

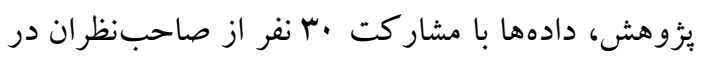

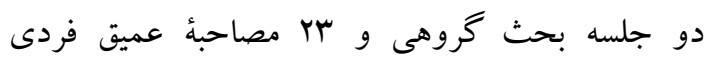

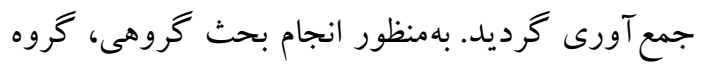

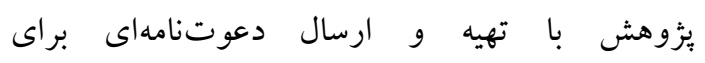

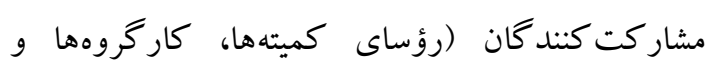
كارشناسان دبير خانهٔ شوراى عالى سلامت V نفر )، عنوان جلسه، اهداف، زمان و محل بركزارى جلسة بحث

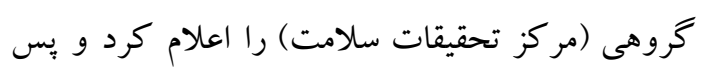


مر اجعه به وبكاه الكترونيك شوراهاى منتخب مشخص

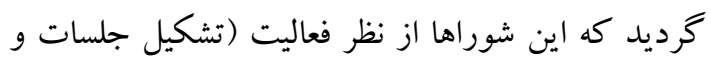
توليد مصوبات) سه دسته هستند (فعال، نيمه فعال و ورديد غير فعال) كه در جدول ذيل آمدهاند.

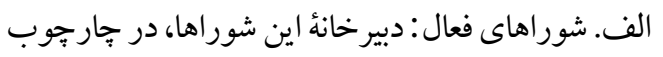

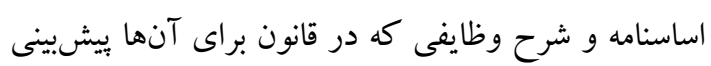

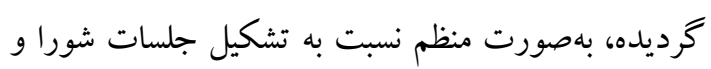
تصويب مصوبات موردنظر اقدام كردهاند. وزير بهداشت و

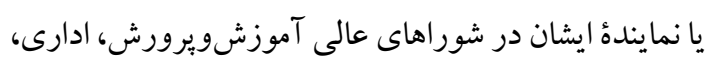
فناورى اطلاعات، حفاظت فنى و بيمه سلامت حضور دارد؛

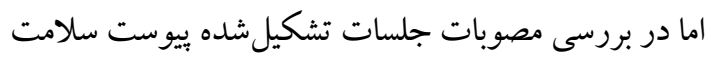
بهورت جشمخيرى در همة مصوبات منظور نشده است كه نشاندهندة بىتوجهى وزير بهداشت و و يا نمايندة شركت كننده در جلسات و نيز اعضاى اصلى شورا و افراد

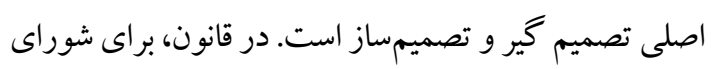

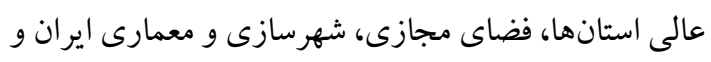

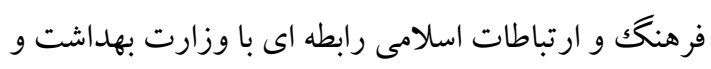
يا شوراى عالى سلامت و امنيت غذايى بيشيينىنشده است راست و علىرغم تشكيل جلسات بهصورت منظم، متأسفانه بيوست سلامت در مصوبات وجود نداشت. ضعف نظام

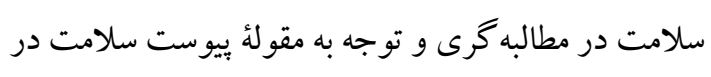
مصوبات شوراهاى مدنظر، بىتوجهى و آكاهى بايين تصميمسازان و تصميم گيران شركت كننده در شوراهاى

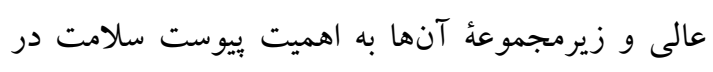

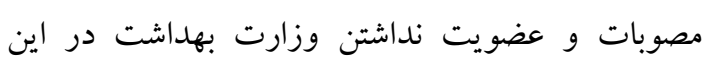

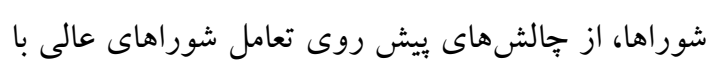
وزارت بهداشت است. ب. شوراهاى نيمه فعال: شوراى عالى جوانان، شوراى

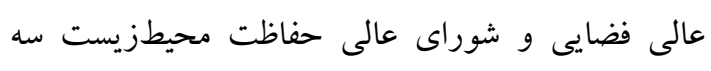

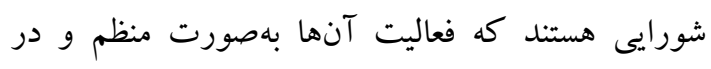
جارجو ب وظايف بيشبينى شده انجام نمى شود. در شوراى

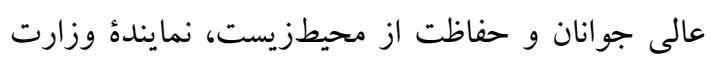

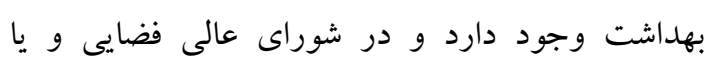

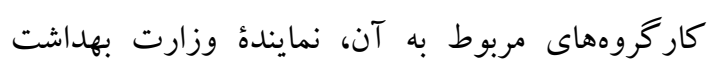

ممكن انجام شد. پِس از بايان هر بخش از بحث گروهى

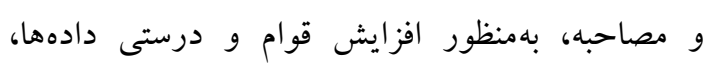
مصاحبه هاى يِيادهازى شده با همكارى مشار كت كنند كان كنترل كرديد. مصاحبه ها هب تا •و دقيقه به طول انجاميد.

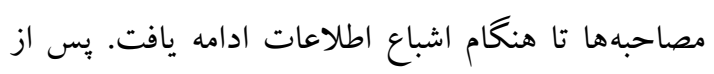

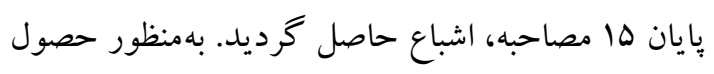

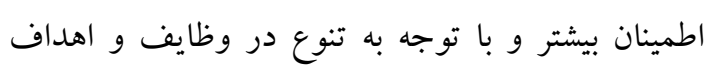

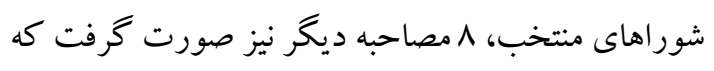

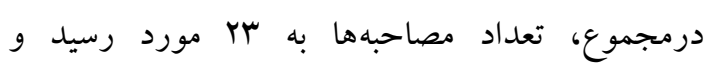

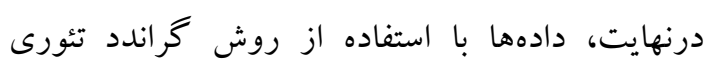
مُّ.

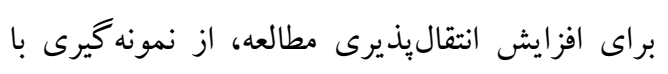

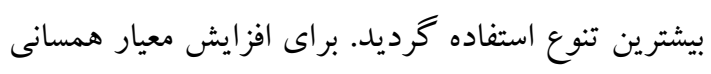

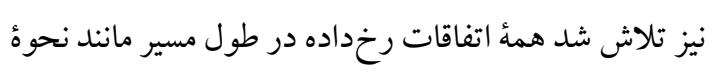

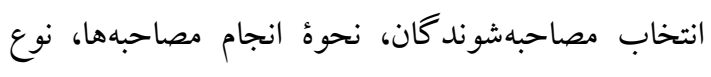

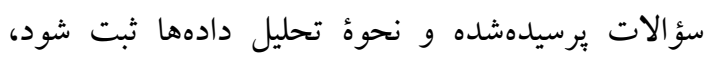
بهورى كه ديخران تا حد امكان با جزئيات مطالعه آشنا

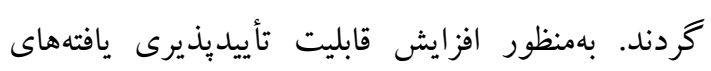
مطالعه (كه درواقع به اين موضوع مىيردازد كه يافتهها

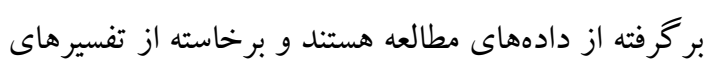

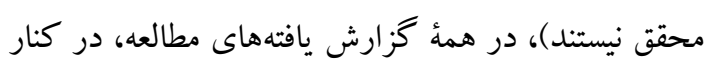

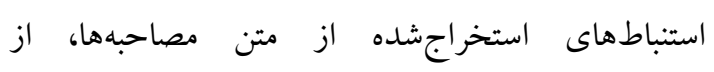
نقلقولهاى خود مصاحبهشوندهها استفادهده است.

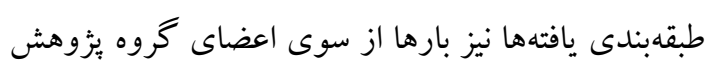

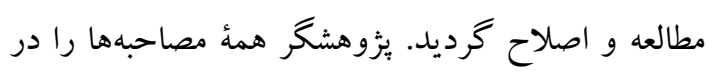

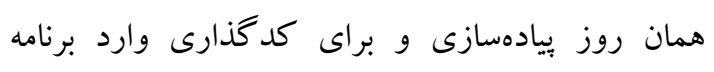

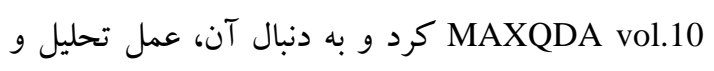
كددهى مطابق الكوى بيشنهادى استراس و كوربين انجام

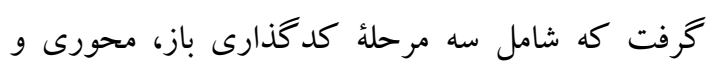

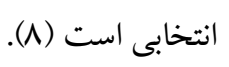

\section{يافته ها}

وضعيت موجود شور/هاى عالى منتخب ازنظر فعاليت:

بر اساس بررسىهاى بهعمل آمده از طريق مصاحبه و والى 

حدود دو ساعت طول مى كشد. بِ ما در موضوع جلسات شورا، با دو مشكل مواجه هستيم: يكى زمان تشكيل جلسات كه دير انجام مىشود، دوم اينكه مدتزمان جلسات كم است؛ درنتيجه، خيلى موضوعات مهم مطرح

$$
\text { بُ. شور اهاى غير فعال شامل: }
$$

ا. شوراى نظارت بر اسبابازى كود كان: اين شورا زير نظر شوراى عالى انقلاب فرهنكى است و مديريت آن بر عهدة كانون يرورش فكرى كودكان و نوجوانان قرار دارد. علاوه بر نظارت بر طراحى، توليد و واردات اسباببازى، نظارت بر فضاى بازى، جمع آورى شواهد و تحقيقات انجامشده درباره بازى و اسباببازى و نيز فرهنكسازى و تغيير در نكرش جامعه نسبت به موضوع اسباب بازى از ديخر وظايف اين شوراست. ارتقاى سلامت و تكامل اوايل كودكى بهعنوان يكك عامل اجتماعى مؤثر بر سلامت، نيازمند اتخاذ راهبردهاى همكارى بين بخشى و مشاركت جامعه است. متأسفانه شوراى يادشده از دو سال كذشته، به سبب همكارى ضعيف اعضاى شوراو نيز پِيين بودن سطح آگاهى سياست گذاران، مديران، مربيان، خانوادهها و والدين دربارهُ نقش بازى و آموزش بازى محور در سلامت و اوايل دوران كودكى و همجنين فقدان شوراى ملى بازى كودكان تعطيل است. يكى از مصاحبهشوند كان دبيرخانه شوراى عالى نظارت بر برى

معاونت جوانان وزارت ورزش و جوانان در مصاحبهاى

با روزنامه دنياى اقتصاد در تاريخ \/F/ وها بيان مىدارد كه: مناسبات و مشاهدات درونى و بيرونى طى اين 9 سال اينطور مى گويند كه نتيجه ادغام جوانان در ورزش بهحدى اشتباه بود كه مسئولان هر دو بخش در ميدان عمل، به تنگنا آمده و به ناكار آمدى وزارتى مشتر كك بارها و در

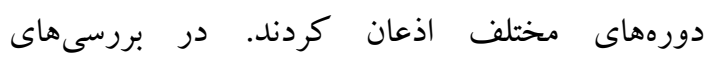
بهعمل آمده از منابع مختلف و سايتهاى معتبر جنين برداشت مىشود كه وزارت ورزش و جوانان در زمينه

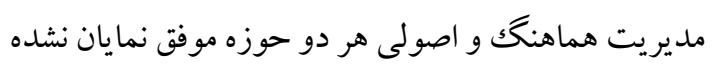
است، به طريقى كه يكى از مصاحبهشوند أنان شوراى عالى جوانان بيان داشتند: (از مشكلات ساماندهى امور جوانان، مشغول بودن وزير ورزش و جوانان به حوزه ورزش است و كمتر به موضوع جو انان برداخته مىشود.|) شوراى عالى فضايى شورايى است كه برخلاف اساسنامه و اهداف اوليه، فعاليتهايش بهدرستى انجام نمىشود. انتقاد از عملكرد شوراى عالى فضايى به اين علت مطرح مىشود كه برخلاف اساسنامه، اين شورا از بدو تشكيل (سال سرץ|) تاكنون درمجموع r جلسه داشته است. در اين زمينه، رئيس سازمان فضايى ايران اظهار داشت: برنامهُ · إ سالهُ اول فضايى از سال هیبا آغاز شد و تا سال هوسا ادامه داشت كه اين برنامه مبتنى بر توسعه فناورى فضايى و بومىسازى آن بود. در اين مدت نيز بار شوراى عالى فضايى تشكيل شد و موارد لازم در شورا به تصويب رسيد. به سبب ويز گیىهاى منحصربهفردى كه در فضا وجود دارد، توسعه درست و اصولى فناورى فضايى مى تواند تمام زواياى زندگى مردم را دگر گون كند و تأثير زيادى در سلامت جامعه داشته باشد (در جدول شمارة ب به

$$
\text { نقش شورا اشارهشده است). }
$$

شوراى عالى ديخرى كه از نظر جايگاه و نقش، در حوزه فعاليتش اهميت بالايى دارد، شوراى عالى حفاظت از محيطزيست است كه متأسفانه به سبب مشكلات و و جالش هاى موجود، بهصورت فعال ظاهرنشده است و در 


\begin{tabular}{|c|c|c|}
\hline وظايف كليدى مندرج در مستندات قانونى & شوراهاى عالى & \\
\hline 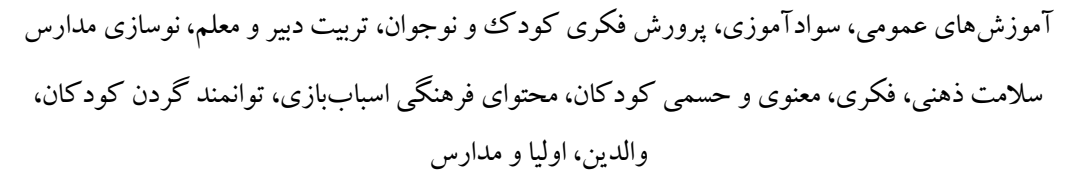 & 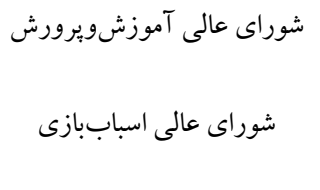 & $r$ \\
\hline زمينههاى اشتغال و ازدواج جوانان، اوقات فراغت جوانان، تقويت خصوصيات روحى، اخلاقى، فكرى و & 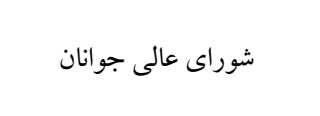 & $r$ \\
\hline توسعهُ تسهيلات و امكانات ورزشى، سياستهاى ورزش همكانى، ورزش قهرمانى & 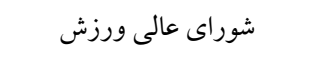 & f \\
\hline بهرهورى نيروى انسانى و مديريت دستكاههاى اجر ايى، بهينه سازى ساختار، تركيب و توزيع نيروى انسانى، & شوراى عالى ادارى & $\Delta$ \\
\hline ييخيرى مشكلات ييشنهادى استانها، بيان نارسايىها و اشكالات نهادها و سازمانهاى اجر ايى & 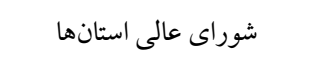 & 9 \\
\hline دولت الكترونيكك و كاهش هزينهاى خانوار، استفاده از ظرفيتهاى شورا براى ارتقاى سلامت مردم & شوراى عالى فناورى اطلاعات & $V$ \\
\hline 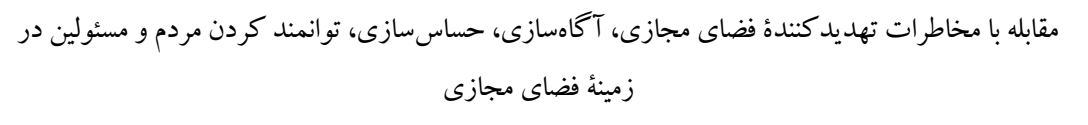 & شوراى عالى فضاى مجازى & $\wedge$ \\
\hline به كار گيرى فناورىهاى فضايى در زمينهاى امنيتى، توليدى، بهداشتى و...، بيشبينى مخاطرات طبيعى ماند & 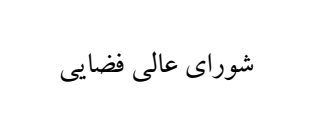 & 9 \\
\hline محيط كار سالم (كاهش حوادث شغلى و استفاده از فرصت محل كار براى ارتقاى سلامت)، حفاظت فنى & 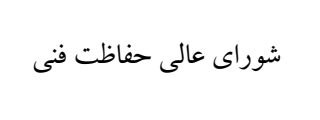 & 1. \\
\hline 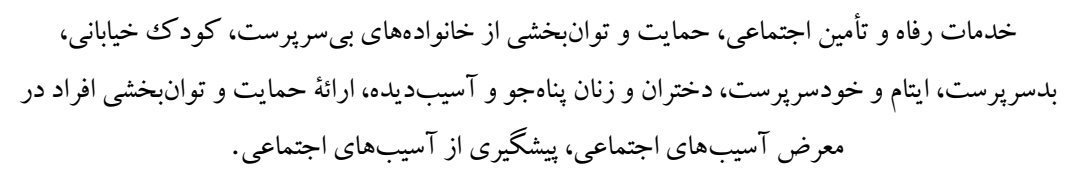 & 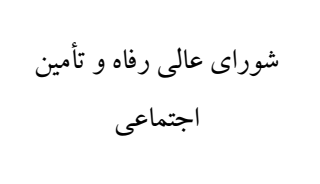 & 11 \\
\hline 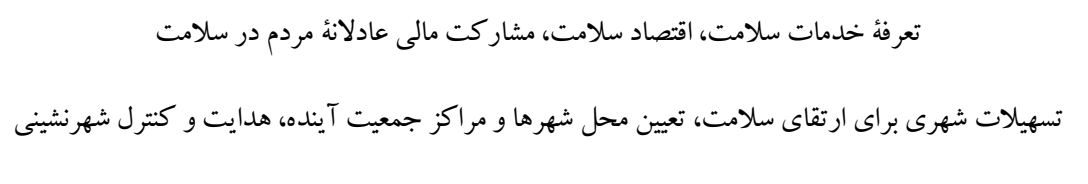 & $\begin{array}{l}\text { شوراى عالى بيمة سلامت عاى عالى شهر سازى و } \\
\text { شعمارى ايران }\end{array}$ & ir \\
\hline 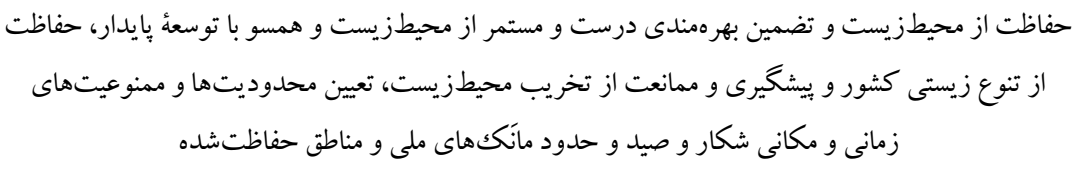 & شوراى عالى حفاظت & If \\
\hline تهية سامانهاى هوشمند و شناسايى معاملات مشكو كك و گزارش به مراجع ذىربط براى انجام اقدامات لازم، & 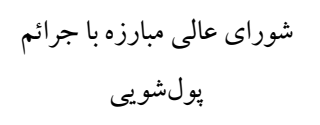 & 10 \\
\hline 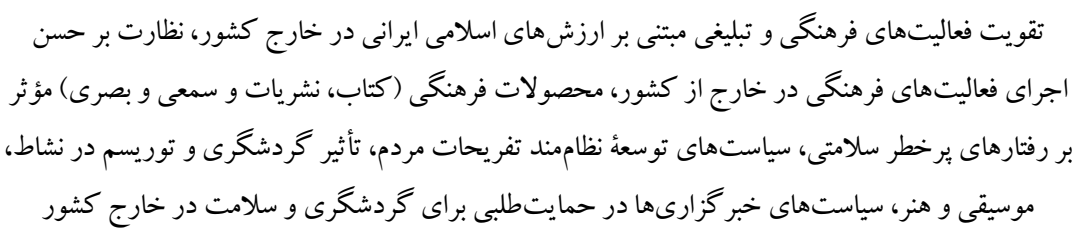 & شوراى عالى فرهنگك و & 19 \\
\hline 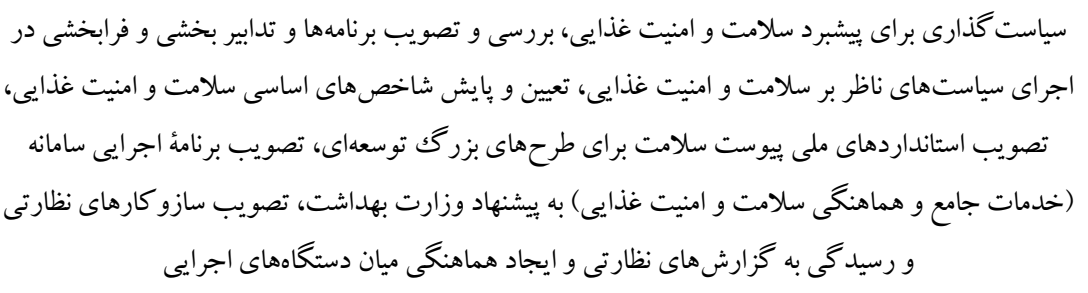 & شوراى عالى سلامت و امنيت & IV \\
\hline
\end{tabular}


مى گرفت. با عنايت به اين مسئله، هم وزير بر موضوعات

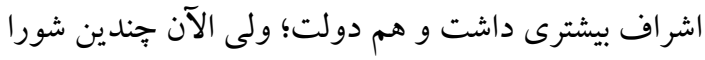
در بدنهُ وزارت تعاون، كار و رفاه اجتماعى فعاليت

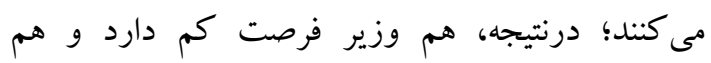
رئيس جمهور فرصت شركت در جلسات را ندارد. به سبب دمب دردي

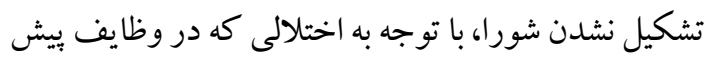

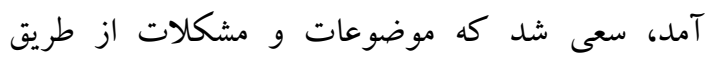

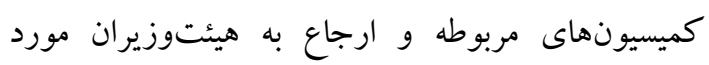
تصويب قرار گيرند.

F. شوراى عالى مبارزه با جرائم يولشويى: اين شورا در سال Vوץ ا، با موافقت مجلس شوراى اسلامى، بهمنظور

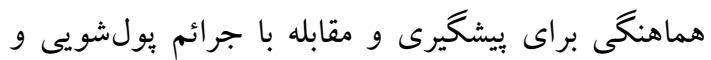

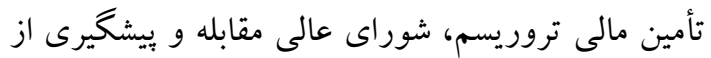

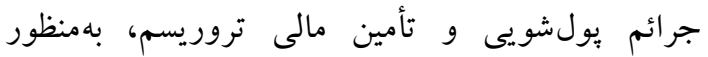

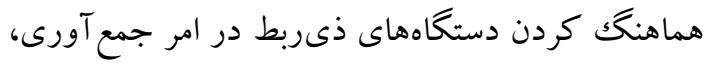
يردازش و تحليل اخبار، اسناد و مدارك،، اطلاعات و كزارش هاى واصله، تهية دستخاههاى اطلاعاتى هوشمند، شناسايى معاملات مشكو كك و بهمنظور مقابله با جرم هرمائه

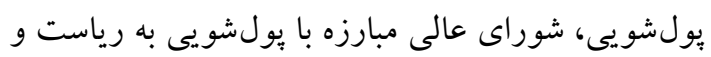
مسئوليت وزير امور اقتصادى و دارايى تشكيل گرديد.

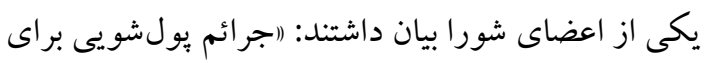
اكثريت مردم و سياست گذاران مخصوصاً در بخش إنش

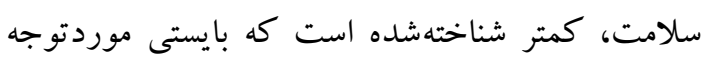

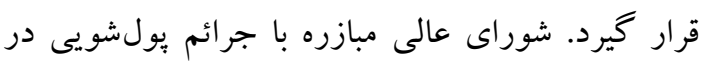

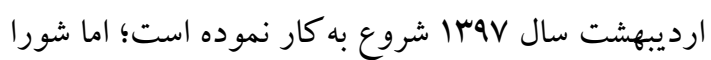

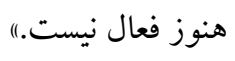

نقش شور/هاى عالى منتخب در سلامت: بهمنظور تعيين

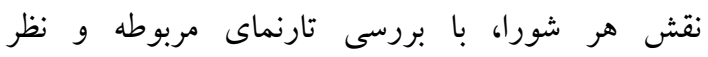

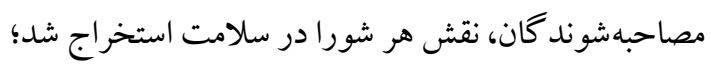

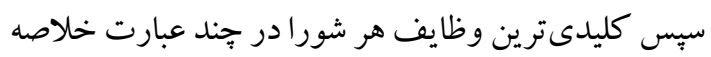
شده و جدول بيشنويس نقش شوراها براى نظرخو اهى از برخى از شركت كنند گان در مصاحبه آماده گرديد.

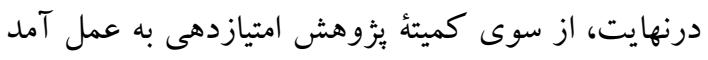

اسباببازى بيان داشتند: اشورا • ا عضو دارد كه از سال اربا تاكنون، •r جلسه تشكيلشده است. جلسات شورا در مدت 1/ ماه كذشته، به علت عدم همكارى اعضاء تشكيل نشده است." مر مات باه r. شوراى عالى ورزش: توسعهُ ورزش همگانى و و نهادينه كردن فرهنگ ورزش در ميان آحاد مردم جامعه ورنه

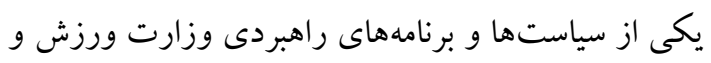
جوانان است. براى تحقق اين مهم، شوراى ورزش همكانى

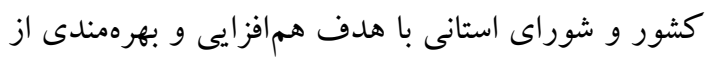

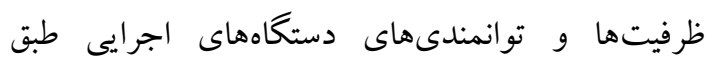

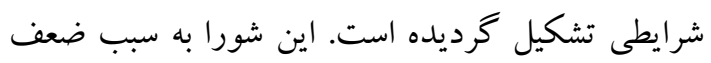

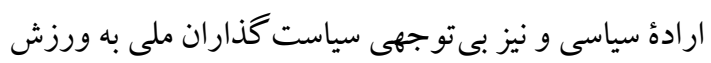

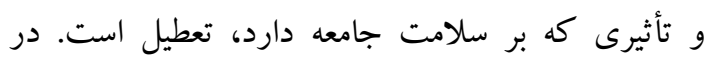
مصاحبه با يكى از شركت كنند كان عضو دبيرخانهُ شوراى

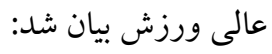
"اين شورا با نام "شوراى تربيتبدنى و تفريحات

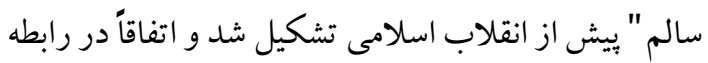

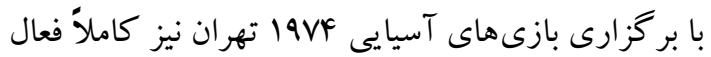
بود. اين شورا بعد از انقلاب هم به حيات خود ادامه داد.

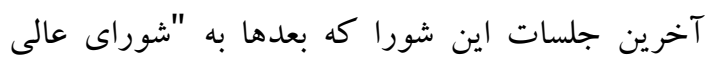

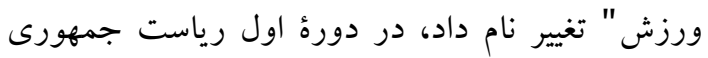

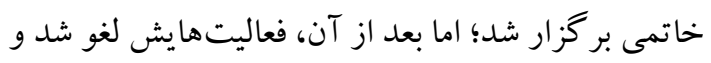

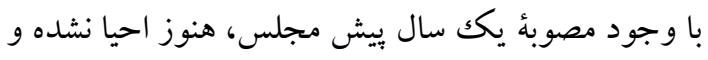

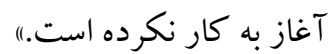

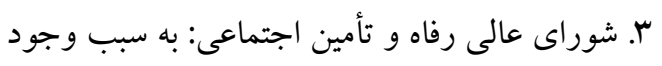

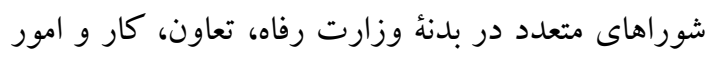

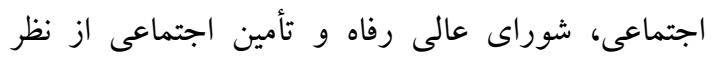

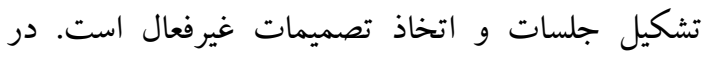

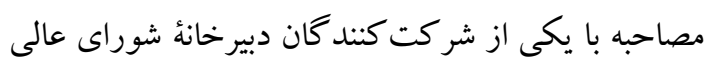
رفاه دربارة تعطيلى شورا اشاره داشتند كه: اشوراى عالى رفاه به استناد قانون ساختار نظام جامع

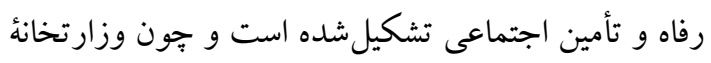
مستقلى داشت، همة مسائل مربوط به رفاه در اينجا انجام 
تحليل دادهها و مصاحبه با ذى نفعان كليدى، سه موضوع اصلى شناسايىشده بيش روى شوراهاى عالى در تعامل با داديا

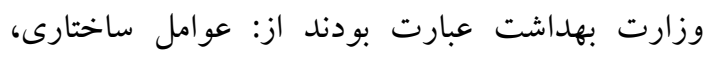

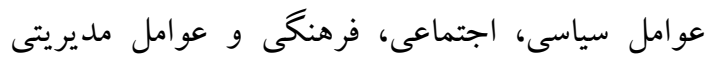
(جدول شمارهء r).
(جدول شمارة ץ). براى تعين نقش از بررسى مستندات

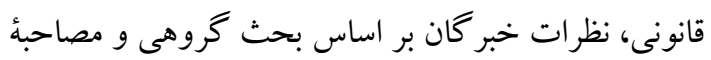
حضورى اعضاى دبيرخانه شوراهاى عالى و دبيرخانه شوراى عالى سلامت استفاده شده است.

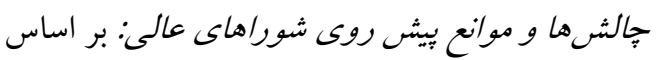

جدول rا. موضوعات اصلى و مشكلات شناسايى شده شوراهاى عالى در تعامل با وزارت بهداشت

\begin{tabular}{|c|c|}
\hline 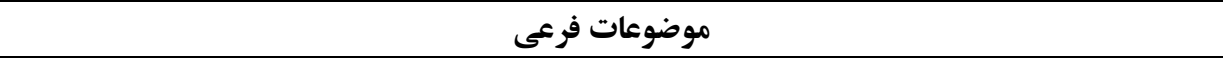 & 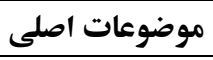 \\
\hline \multicolumn{2}{|l|}{ I. كمبود منابع مالى و انسانى مكفى و مناسب، r ساختار ناكار آمد، ب. نبود عزم و ارادة جدى در اجراى مصوبات، F. وجود } \\
\hline قوانين و مقررات موازى و تداخل وظايف،ه. ضعف در اجراى مصوبات به علت ضمانت اجر ايى ناكافى، 9. تعامل با & 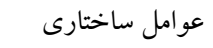 \\
\hline شوراهاى عالى طبق كدام ساختار و توسط كدام نهاد زيرمجموعهُ وزارت بهداشت؟ & \\
\hline \multicolumn{2}{|l|}{ 1. آكاهى و نكرش يايين تصميمسازان و تصميم گيرند گان شوراهاى عالى دربارهٔ سلامت و عوامل مؤثر بر آن، ب. آكاهى } \\
\hline \multirow{3}{*}{\multicolumn{2}{|c|}{ 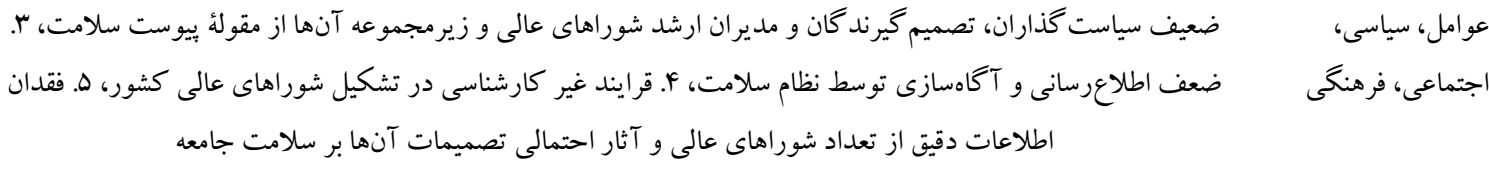 }} \\
\hline & \\
\hline & \\
\hline \multicolumn{2}{|l|}{ 1. نبود برنامههاى مؤثر و مدون در دبيرخانهُ شوراهاى عالى، Y. فقدان نظام يايش و ارزشيابى مستمر و يويا، ب. ضعف } \\
\hline \multicolumn{2}{|l|}{ مديريت و همكارى بين بخشى، F. توليت (رهبرى) ضعيف وزارت بهداشت در برون بخش سلامت، ه. مهارت ضعيف } \\
\hline وزارت بهداشت و زيرمجموعههاى آن در استفاده از فن حمايت طلبى، 9. نداشتن تفاهمنامه و قرارداد با بيشتر شوراهاى & \\
\hline عالى و دستگاههاى اجرايى & \\
\hline
\end{tabular}

در هر سازمانى بهخودىخود هدف نيست، بلكه وسيلهاى براى دستيابى به اهداف سازمان و اجر اي مؤثر و موفقيت آميز وظايف و مسئوليتها است. هر شوراى عالى بايد ساختار سازمانى و تشكيلات مؤثرى داشته باشد، بهطورى كه وظايف و مسئوليتها، بهوضوح ميان واحدهاى مختلف زير مجموعه تقسيم شده و به آنها قدرت اختيار در برابر مسئوليتها و وظايف دادهشده باشد. بر اساس دادههاى مطالعه، ساختار و تشكيلات ناكارآمد و كمبود نيروى انسانى متخصص از موانع اصلى تعامل است. يكى از مصاحبهشوندكان بيان داشت: (اهرجند همه به اين موضوع اذعان داريم كه اجرا و اصلاح هر قانون و مقرراتى نيازمند ساختار مناسب و منابع مالى و انسانى موردنياز است كه در صورت محقق نشدن اين عوامل، نتيجهُ دلخواه به دست نخواهد آمد)(م F).

ا -r. وجود قوانين و مقررات موازى و تلداخل وظايف باعث اخلال در اجراى مصوبات: فرايند غير كارشناسى در

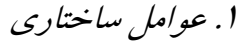
1 -1. كمبود منابع مالى: كمبود منابع مالى و اعتبارى مشكلى است كه عملكرد شور اهاى عالى و دبيرخانهُ آنها رادر سطح ملى با جالش جدى مواجه كرده و باعث شده است كه بيشتر آنها عملكرد قابل قبولى نداشته نباشند كه در مصاحبه ها به كرات بيانشده است؛ بهعنوان نمونه، يكى مصاحبهشوند كان اظهار داشت: (بيشتر شوراهاى عالى به دليل مشكلات مالى و اعتبارى كافى مؤثر نيستند. از طرفى، سازمان برنامهوبودجه هم مطالبه شوراهاى عالى نقش رگلاتور توسعه كشور رادارند و اكر شورايى نمىتواند مؤثر باشد و انجاموظيفه كند بايستى حذف شود در غير اين صورت بايد فعالانه در جهت وظايف شورا اقدام نمايد)،(م r). 1 r.r. ساختار و تشكيلات نامناسب شوراهاى عالى و زيرمجموعة آنها: بهطور كلى، ساختار و تشكيلات ادارى 
اين زمينه، بسيار اثر گذار خواهد بود. اعتقاد به مقولهٔ

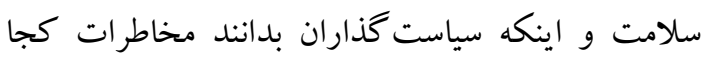
زيانبار هستند، از مقولات بسيار مهم است كه نظام

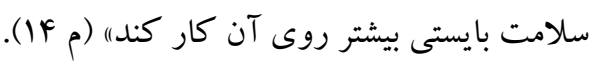

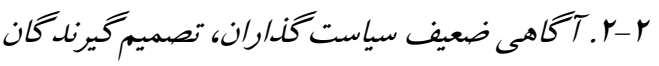

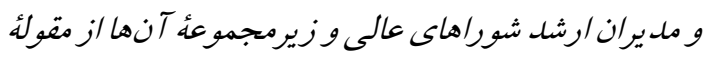
بيوست سلامت: علىرغم وجود الزام قانونى، متأسفانه بى خبرى بيشتر شوراها از قوانين و مقررات بالادستى سبب

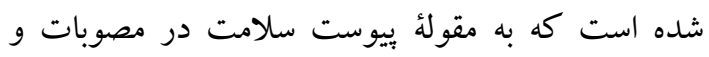

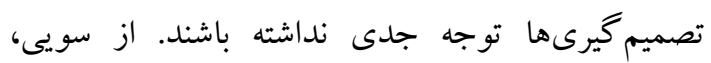

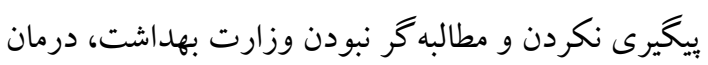

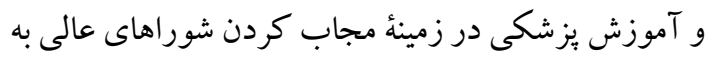
در نظر گرفتن مقولهُ سلامت در هنگام اتخاذ تصميم و يا

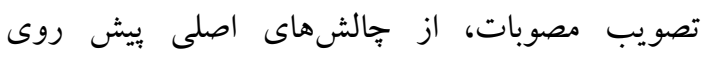
شوراهاى عالى و نظام تصميم سازى و تصميم گيرى كشور

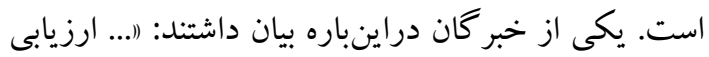
سلامت در خصوص مصوبات و تصميمات شورا انجام نمى شود. البته در حوزة اجرا بايستى به اين موضوعات توجه

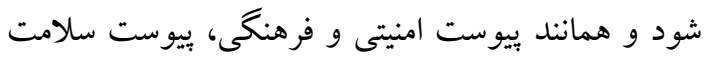
هم ديده شود كه اين كار انجامنشده است؛ مثلاً در زمينٔ

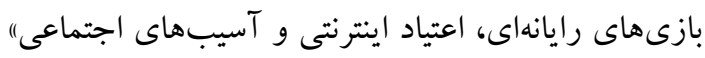

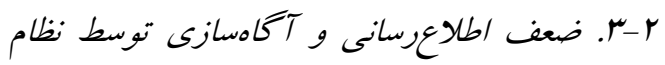

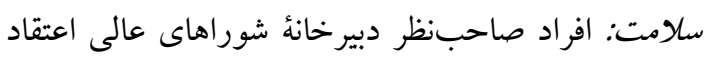

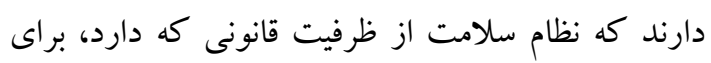

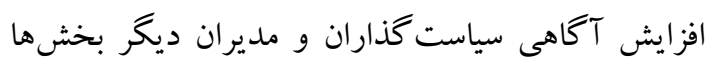
نسبت به مخاطرات تهديد كنندة سلامتى استفاده نمى كند:

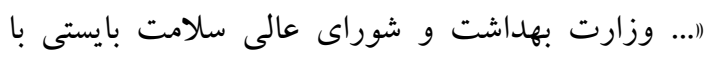

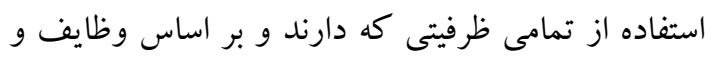

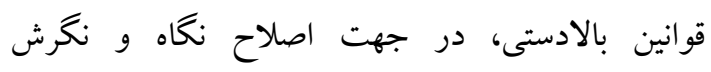
سياست گذاران، تصميمسازان و تصميم گيران ارشد در دراه سطح ملى در خصوص ورزش و سلامت اقدام كندا) (م F).
تشكيل و ايجاد شوراهاى عالى در كشور كاهى سبب مىشود كه موازى كارى و تداخل وظايف در دستخاههاى

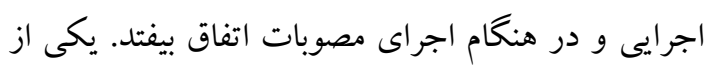

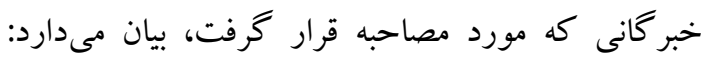

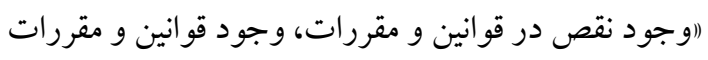

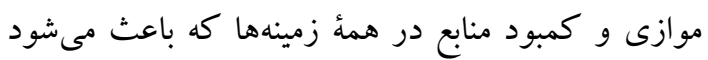

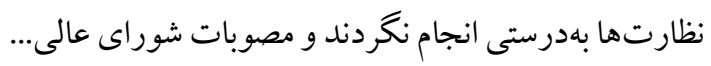
در اجرا مشكل داشته باشند) (م 9).

1F- أ اجراى ضعيف مصويات به علت ضمانت /جرايى ناكافى: از ديخر جالشها و موانعى كه شوراهاى عالى دررسيدن به اهداف از ييش طراحى دشده و لحاظ كردن بيوست سلامت در مصوبات با آن مواجه هستند، بشتوانه

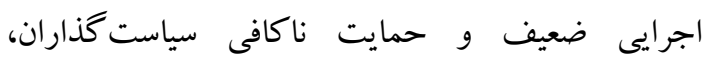
تصميم گيران و مديران ارشد در سطوح مختلف نظام تصميم گيرى و اجرايى است. اجراى مصويات شوراهاى

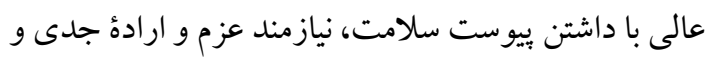
وجود ضمانت اجرايى محكم در عرصه و نيز هنكام اجرا است. در اين رابطه، يكى از افرادى كه در مصاحبه شر كت داشتند، دراينباره بيان كردند: (از مشكلاتى كه شوراهاى

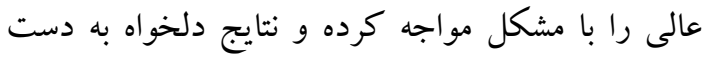
نمى آورند، عدم وجود ضمانت اجر ايى و عزم و اراده در

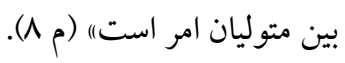
r. بوامل سياسى، اجتماعى و فرهنكى

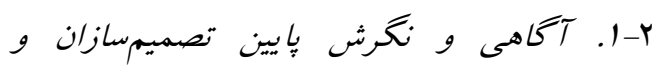

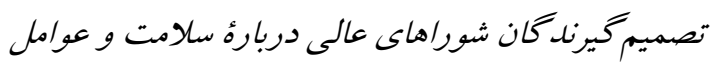

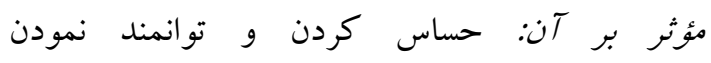

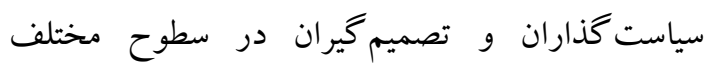

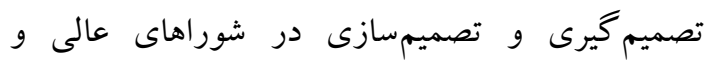

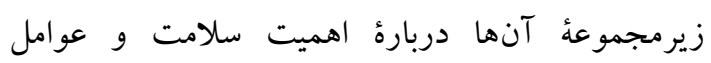

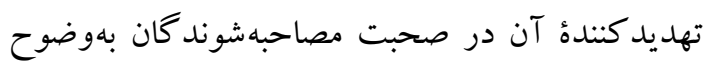
بيانشده است: (آموزش و حساس سازى در موضوعات سلامت و تو انمند كردن تصميم سازان و تصميم گير ان در 


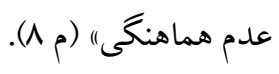

r r-r ضعeف ملديريت و همكارى بين بخشى: همافزايى

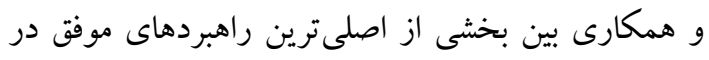

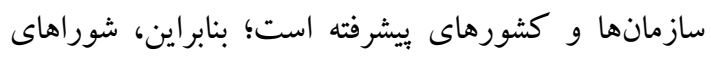

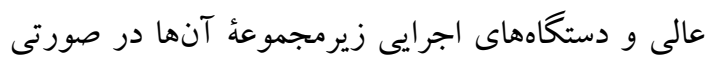

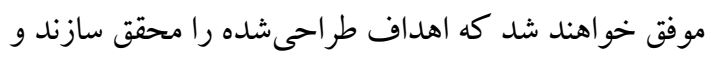
در فرايند همكارى و هماهنگىى، اصول مربوطه را بهدرستى

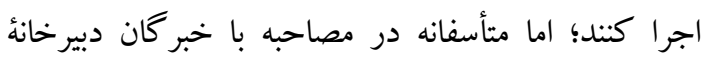

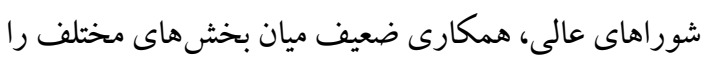
بهنوان مشكل بيان كردند. يكى از خبر گان دراينباره

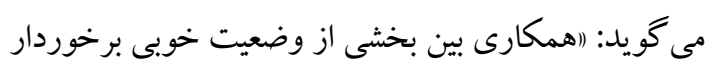

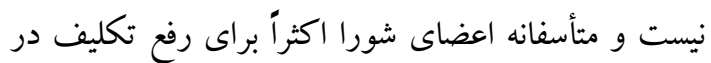
جلسات شورا شر كت مى كند، حتى خود وزارت بهداشت هم متأسفانه همين رويكرد و رفتار را دارد) (م Y Y Y).

r-F- F- توليت (رهبرى) ضعيف وزارت بهد/شت، ورمان و آموزش بزشكى: بر اساس قانون، توليت يعنى حاكميت درون بخش و رهبرى برون بخش از وظايف وزارت

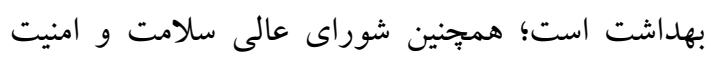

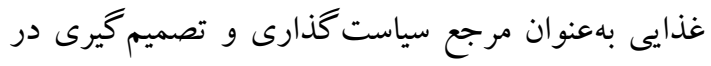

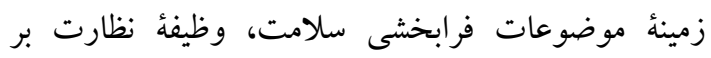

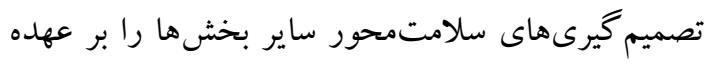
دارد كه متأسفانه دراينباره بهدرستى انجاموظيفه نكرده

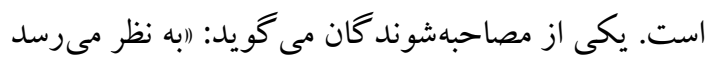

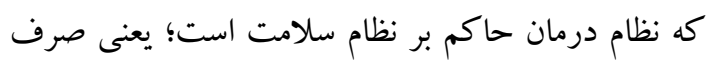

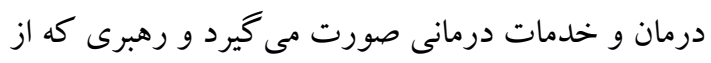
وظايف نظام سلامت است؛ يعنى رهبرى برون بخش، تقرئ درمياً

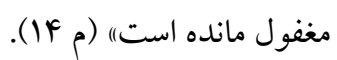

\section{بحث و نتيجه كيرى}

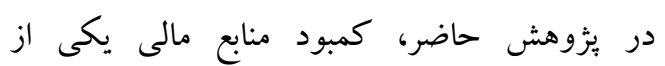

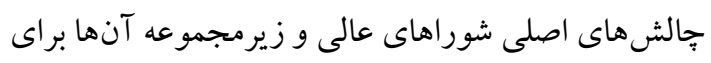
اجراى مصوبات و اهداف ييشبينى شده بود كه با يافتهاى

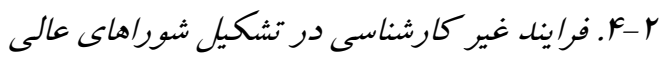
كشوز: بر اساس بررسىهاى بهعمل آمده از سايتهاى

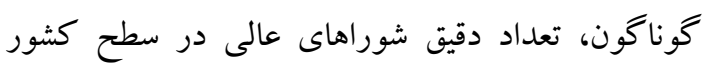
نامشخص است و روند مشخص و متولى شناختهشدهاى دربارة ضرورت تشكيل شوراهاى عالى و نظارت بر روند

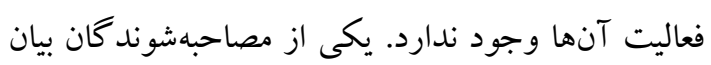
داشتند: (اتشكيل و يا عدم تشكيل شوراهاى عالى بيشتر اوقات زمينههاى سياسى دارده) (م Y).

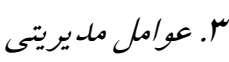

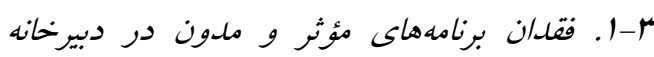

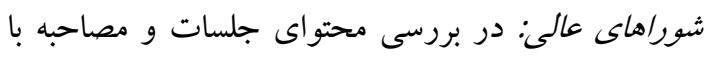

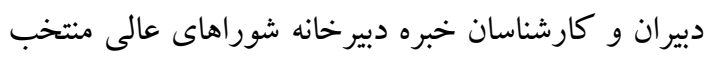

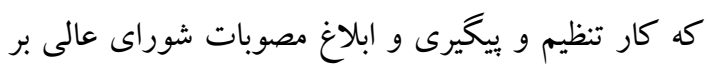

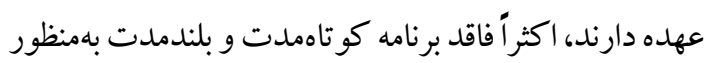

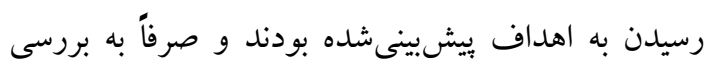

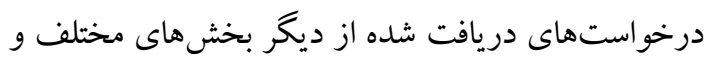

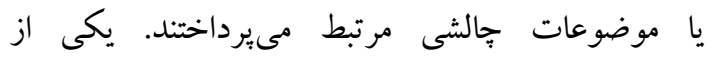
مصاحبهشوندكان بيان داشتند: (متأسفانه بايستى اذعان داشت مانت كه گريز از رويكرد برنامه محورى و برنامهريزى در سطوح دئن مختلف سيستم ادارى كشور بهوضوح نمايان است كه شوراهاى عالى هم از اين رويكرد بى نصيب نيستند) (F F).

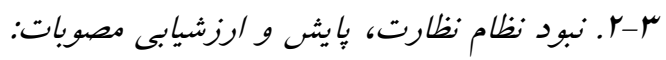

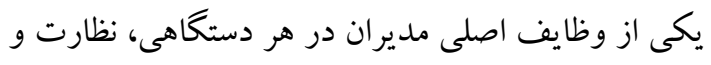

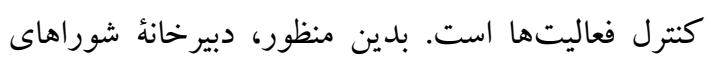

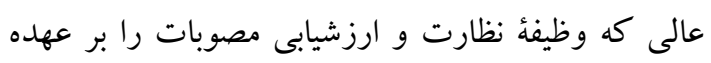

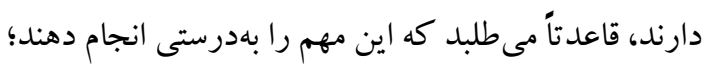
اما به علت ضعف در همكارى و هماهنكى اعضاى شورا،

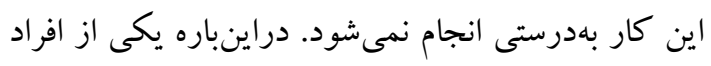

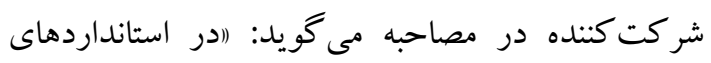

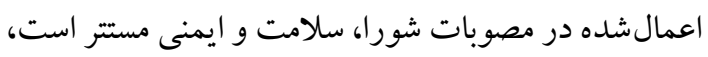

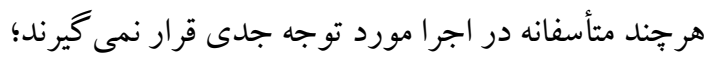

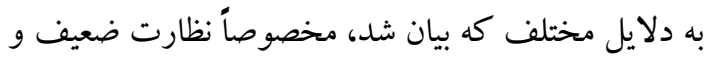


نقش بسز ايى در بيشبرد قوانين مرتبط با سلامت دارد (19). آكاهى و نكرش يايين تصميمسازان و تصميم گيران شوراهاى عالى دربارهُ سلامت و عوامل تعيين كنندهُ آن و همجنين بىتوجهى به بيوست سلامت در مصوبات و سياست گذارىها به علت ضعف آكاهى از تأثيرات و عواقب آنها بر نشانكرهاى سلامت جامعه، از ديخر جالشهاى اصلى تعامل شور اهاى عالى با وزارت بهداشت است كه با مطالعات مصدقراد و رحيمى تبار (F) (I)، دمارى و همكاران (·r)، دمارى و همكاران (Y) (Y) و جونز (YY) همخوانى دارد. حمايتطلبى توسط نظامهاى سلامت بهعنوان يكك (راهبرد)، نقش محورى درى در تغيير نغاه متصديان سازمانهاى ذىربط دارد؛ بنابراين، در اولويت قرار گرفتن (اسلامت مردم) نسبت به ساير موضوعات حاكميتى و اجتماعى نيازمند تغيير نغاه سياسيون و و تصميم گيرند كان است كه ابزار آن حمايتطلبى است (Y) (Y). علىرغم وجود الزام قانونى، متأسفانه بى خبرى بيشتر شوراها از قوانين و مقررات بالادستى سبب شده است كه به بيوست سلامت در مصوبات و تصميم گيرىها توجه جدى نداشته باشند. از سويى، يُخيرى نكردن و مطالبه نبودن وزارت بهداشت، درمان و آموزش يزشكى در زمينه مجاب كردن شوراهاى عالى مؤثر بر سلامت به لحاظ كردن يُيوست سلامت در تصميم گيرىها و مصوبات، از جالشهاى اصلى بيش روى شوراهاى عالى و نظام

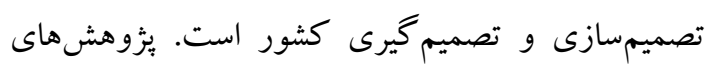

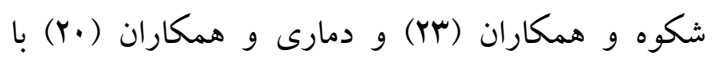
يزوهش حاضر همسو هستند. سازمان جهانى بهداشت سياست گذارى مسئول براى سلامت عمومى را اينطور تعريف كرد: اقرار دادن سلامت در دستور كار سياست گذاران تمام بخشها و تمام سطحها، هدايت سياست گذاران به آكاهى از بيامدهاى تصميمات آنان بر روى سلامتى و بذيرش مسئوليت در قبال سلامت) (YF). متأسفانه نظام سلامت از ظرفيت قانونى كه دارد، براى افزايش آكاهى سياست گذاران و مديران ديخر بخشهام سلها نسبت به مخاطرات تهديد كنندهُ سلامتى استفاده نمى كند.
مصدقراد و رحيمىتبار (F) (F)، سنيىنصب و همكاران (1) و تاهان (19) همخوانى دارد. يافتهها نشان مىدهد كه بيشتر دبيرخانه شوراهاى عالى در كشور از نظر تأمين منابع مالى و اعتبارى استقلال كافى ندارند و اين موضوع بهعنوان يكك جالش جدى باعث شده است كه شوراهاى عالى از نظر برنامهريزى، ارزشيابى و بيخيرى اجراى مصوبات و و توجه به بيوست سلامت در سياست گذارىها، موفقيت جشمخيرى نداشته باشند. كمبود نيروى انسانى موردنياز، ساختار و تشكيلات ناكار آمد و وجود قوانين و مقررات موازى از ديخر جالشهاى عوامل ساختارى است. بهطوركلى، كمبود نيروى انسانى از نظر كمى و كيفى وجود دارد و طرحهاى آموزشى بر اساس نيازهاى شوراهاى عالى بازبينى نمىشود، بيشتر دبيرخانهُ شوراها

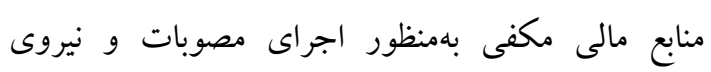
تخصصى را ندارند و از ساختار و تشكيلات استاندارد برخوردار نيستند. بهمنظور ارتقاى كمى و كيفى نيروى

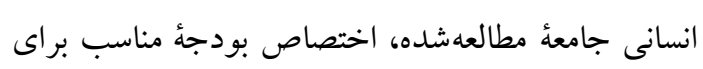
جذب نيروى انسانى به تعداد لازم، بهويزه نيروهاى تخصصى و تربيت كاركنان آموزشديده و دورهديدة

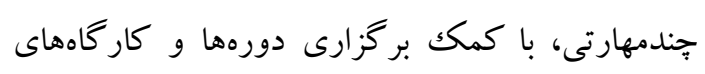
آموزشى، براى ايجاد كردش شغلى در شرايط كمبود نيرو و نيز تخصيص منابع مالى موردنياز ييشنهاد مى گردد. علاوه بر اين، عزم و ارادهُ سياسى در اجراى مصوبات و سياستها از جالشهاى اصلى ساختارى در تعامل شوراهاى عالى با وزارت بهداشت است كه با مطالعات وحدانىنيا و وثوق مقدم (IV) و وحدانىنيا و ملككمحمدى (IN) مطابقت دارد. اجراى مصوبات در محيط و توسط دستخاههاى اجرايى نيازمند عزم و اراده سياسى و نيز ضمانت اجرايى ماردي

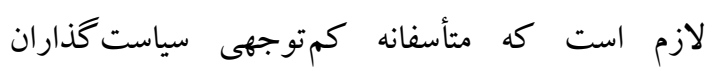
دراينباره باعث شده است كه فعاليت شوراها اثربخشى قابل توجهى بهويزه در زمينه عو امل مؤثر بر سلامت نداشته باشد. مسئوليتيذيرى سياسى نقش فراوانى در اثربخشى بـى قوانين و مقررات سلامت كشورها دارد. اقتدار دولت مركزى و هماهنگى و حمايت مجلس نمايند گان مردم 
وزارت بهداشت و شوراهاى عالى از الزامات اصلى بهبود عادلانه شاخصهاى سلامت در كشور است. بر اساس يافته هاى مطالعه و مطالعات بيشين، نقش و سهم شور اهاى عالى مؤثر بر سلامت در بهبود شاخص هاى سلامت از اهميت بالايى برخوردار است. عوامل فراوانى بر عملكرد اين شوراها تأثير دارند كه به تفصيل موردبحث قرار گر فتند. كم كردن مشكلات شوراهاى عالى و استفاده از راهبرد حمايتطلبى، همكارى بين بخشى و ديخر راهبردهاى مؤثر و به كاركيرى تجربيات ديخر كشورها مىتواند همسو با بهبود و ارتقاى سلامت جامعه باشد. بر اساس يافتهاى مطالعه بيشنهاد مىشود عملكرد شوراهاى عالى كه تصميمات آنها بر سلامت جامعه مؤثر است، از طريق مداخلات (سياستى، عملياتى، فرهنگك سارى) زير تقويت گردد:

دستئ اول. مداخلات سياستى: ابلاغ دستورالعمل ارزيابى سلامت به همهُ دبيرخانه شوراها و كارگروهها و كميتهاى تخصصى از طريق دبيرخانهُ شوراى عالى سلامت و امنيت غذايى با امضاى بالاترين مقام اجرايى كشور، بهعنوان اولين كام در بهبود عملكرد بهشمار مى آيد؛ تعين ضمانت هاى اجرايى مصوبات در قالب يك آيين نامه و ابلاغ آن به همهُ وزارتخانهها و دستكاههاى اجرايى؛ الزام همه وزرا و روساى دستخاههاى اجرايى در سراسر كشور به توجه ويزٔه به اجراى مصوبات با داشتن بيوست سلامت در جار جوب سند توسعة سلامت كشور و نيز در همهٔ استانهاى محل اجرا. لازم است شوراى عالى سلامت و امنيت غذايى سياست كذارى كند و به همءٔ دبير خانه شور اهاى عالى و وزارتخانهها و استاندارىها ابلاغ نمايد تا از اين طريق، حمايت و ضمانت اجراى مصوبات ارزيابىشده از نظر سلامت بهوجود آيد؛ اختصاص بودجئ كافى و مناسب براى دبيرخانه شوراهاى عالى بر اساس نقشها و يروزههاى تعريفشده (لازم است مديريت برنامهوبودجه بهعنوان ر گلاتور، در توزيع بودجهُ دبيرخانه شوراها توجه ويزهاى داشته باشد)؛ برگزارى جلسات هم انديشى و هماهنكى و همايشهاى فصلى و ساليانه
سياست گذاران و مديران نظام سلامت بايد بهطور دائمى با مدير ان ساير بخش ها و همين طور با نمايند كان مردم و افراد بانفوذ جامعه در تعامل باشند تا موضوعات سلامتى را در سياستهاى بخشهاى گوناگون دولت لحاظ كنند و به بهبود عوامل اجتماعى تعيين كنندهُ سلامت در همهُ جامعه كمك كنند (YD). فرايند غير كارشناسى در تشكيل شوراهاى عالى از جالشهاى ديخر شوراهاى عالى در كشور است. بر اساس بررسىهاى انجامشده، تعداد دقيق شوراهاى عالى در سطح كشور نامشخص است و روند مشخص و متولى شناختهشدهاى درباره ضرورت تشكيل شوراهاى عالى و نظارت بر روند فعاليت آنها وجود ندارد. يوراحمد و همكاران (Y4) تعداد شوراهاى عالى را هـ.1 شورا ذكر كردهاند. از ميان شوراهاى موجود، بس شوراى عالى بر اساس قانون اساسى، قوانين مجلس يا فرمانها رهبرى و سايرين بر اساس مصوبات هيئت دولت، قوه قضائيه، شوراى عالى ادارى و شوراى عالى انقلاب فرهنگى تشكيلشدهاند. يافتهاى شهروند و حاجى حسينى (YV) با يثوهش حاضر همسو است. نبود نظام نظارت، بايش و ارزشيابى مصوبات از جالشهاى عوامل مديريتى است كه شوراهاى عالى و وزارت بهداشت با آن مواجه هستند. نظارت و كنترل فعاليت ها يكى از وظايف اصلى مديران در

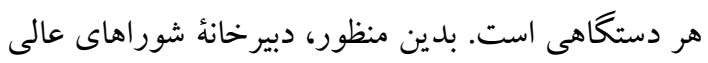
كه وظيفهُ نظارت و ارزشيابى مصوبات را بر عهده دارند، قاعدتاً مى طلبد كه اين مهم را بهدرستى انجام دهند؛ اما به علت ضعف در همكارى و هماهنگى اعضاى شورا، اين كار بهدرستى انجام نمى شود. از ديخر جالش هاى اصلى كه در تعامل شوراهاى عالى با نظام سلامت مشكل ايجاد مى كنند، ضعف وزارت بهداشت در انجام وظايف و نقشهايى است كه بر عهده دارد، همجِنين نبود ساختار مناسب براى همكارى بين بخشى و نيز كم توجهى وزارت بهداشت به رويكرد حمايتطلبى از شور اهاى عالى و ديخر نقش آفرينان ساير بخش ها است. مطالعهُ دمارى و همكاران

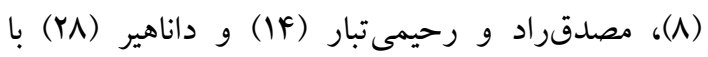
يزٔوهش حاضر همسو هستند. تعامل و همكارى ميان 
با توجه به نتايج اين مطالعه لازم است نظام سلامت و شوراى عالى سلامت براى تعامل با شوراهاى مؤثر بر

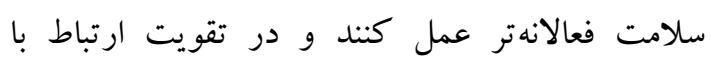
دبيرخانهُ شوراهاى مدنظر، بيشتر از بيش تلاش نمايد. در موضوع اهميت همكارى و تعامل ميان نظام سلامت و شوراهاى عالى، بايد به اين نكته اشاره كنم كه عملكرد شوراهاى عالى و ديخر سازمانهاى برون بخش در زمينهُ

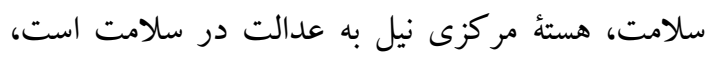

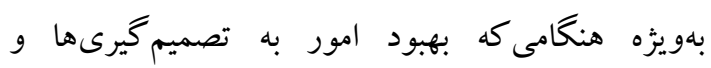
عملكردهاى شوراهاى عالى و بخشهاى ديخر وابسته باشد. از سويى، سلامت يكك موضوع جندوجهى انضباطى است و دستيابى يكك جامعه و يا يكك ملت به آن نيازمند به كارگيرى روشهايى است كه به مشار كت و همكارى جمعى منجر شود. نگًاهى به عوامل تعيين كننده سلامت مشخص مىسازد كه تأمين، حفظ و ارتقاى سلامت جامعه نيازمند مشاركت همگانى است؛ همجنين بدون حضور ديخر نهادهاى تصميم گير و سازمانهاى اجرايى، اهداف سلامت نمى توانند بهطور كامل محقق گردند. اين موضوع را از تعريف سلامت نيز مى توان بهسادكى فهميد. هماهنكى بين بخشى بيانخر همكارى ميان شوراهاى عالى مؤثر بر سلامت و بخش هاى اجرايى و نهادهاى مردمى است و از مهمترين راهبردها براى جذب حضور شوراهاى عالى و ديخر بخشها، سازمانها و افراد، جلب حمايت و تعامل مؤثر و سازنده است. وزارت بهداشت كه سياست گذار و ناظر عالى سلامت كشور است، بايد بهعنوان مدعى و حامى عمل كند و براى افزايش حساسيت مقامات ارشد نسبت به رفع جالشها و موانع مطرحشده و نيز ييامدهاى روند موجود و اثر آن بر شيوع و بروز بيمارىهاى جسمى و روانى هشدار كافى دهد؛ بنابراين لازم است نقشهاى اين وزارتخانه در حيطههاى مختلف مشخص شود. وزارت بهداشت با باتين شناسايى موانع تعامل كه بهتفصيل موردبحث قرار كرفتند، مىتواند بر اساس وظايف تعيينشده در قوانين بالادستى با استفاده از فنون حمايتطلبى و رويكرد همكارى بين
بهمنظور تقويت همكارى بين بخشى با همكارى شوراهاى عالى مؤثر بر سلامت با اولويت تقويت مفاهيم سلامت و مخاطرات تهديدكندهُ آن؛ تهيه و تدوين و ارائه دستور العمل ها و استانداردهاى موردنياز با استفاده از شواهد علمى و يافته هاى بروز دنيا. دستئ دوم. مداخلات ساختار اجرايى: ازجمله مداخلات در اين حوزه، باز مهندسى ساختار و تشكيلات شوراهاى عالى بر اساس نقشها و وظايفى كه بر عهدهدارند، تصويب جارت و تشكيلات دبيرخانه شوراهاى عالى و عوامل زيرمجموعه آنها از طريق سازمان امور ادارى، خود مقدمه و ضمانتى براى استقرار نظام يايش و ارزشيابى مصوبات با همكارى وزارت بهداشت و تقويت مديريت تغييرات است كه مى تواند ييشنياز بهبود عملكرد دبيرخانه شوراهاى عالى و طراحى و بيادهسازى صحيح و مؤثر ساختار دبيرخانه شوراهاى عالى مؤثر بر سلامت باشد. دستئ سوم. فرهنگكسازى و حمايتطلبى: توجيه و و جلب حمايت بيشازيش اعضاى شركت كننده در جلسات شوراهاى عالى و كميتهها و كارگروههاى زيرمجموعه آنها دربارهٔ نقش انسان سالم در توسعه يايدار، تأثير ارزيابى سلامت در همهٔ مصوبات و تأثيرى الئ كه بر شاخصهاى سلامت دارند، بسيار كمك كننده است. بدين منظور لازم است اعضاى شوراهاى عالى و كارگروههاى زيرمجموعة آنها در زمينه نيازهاى آموزشى استخر اجشده در ابعاد \& كانه سلامت (سلامت رهم

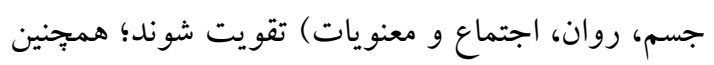
ضرورت دارد اعضاى دبيرخانه شوراى عالى سلامت و امنيت غذايى مهارتهاى همكارى بين بخشى در برخورد

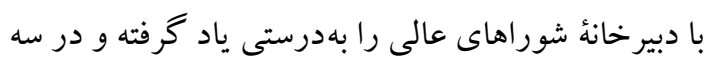
وظيفهُ رهبرى برون بخش، حمايتطلبى و ميانجى گرى دانش توانمند باشند. در همهٔ اين مسير، توانمندسازى نكرشى و مهارتى اعضاى شوراهاى عالى و زيرمجموعة

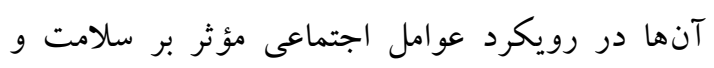
همكارى بين بخشى، موفقيت شوراى عالى سلامت و امنيت غذايى در تعامل با اين شوراها را تضمين مى كند. 


$$
\begin{aligned}
& \text { كارشناسان دبيرخانه شوراى عالى سلامت و نيز } \\
& \text { صاحبنظرانى كه در اين مطالعه شركت داشتند، تقدير و } \\
& \text { تشكر مىشود. } \\
& \text { تعارض منافع } \\
& \text { نويسند گان اعلام مى كنند كه تضاد منافعى در اين }
\end{aligned}
$$

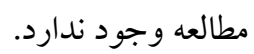

كد اخلاق: 162432750

\section{References}

1. Morone J. An integrative review of social determinants of health assessment and screening tools used in pediatrics. J Pediatr Nurs 2017;37:228. doi. 10.1016/j.pedn.2017.08.022

2. Braveman P, Gottlieb L. The social determinants of health it time to consider the causes of the causes. Publ Health Rep 2014;129:19-31. doi.10.1177/00333549141291S206

3. Vahidi R, Kousha A, Kalantari H, Tabrizi J. Social determinants of health and their related organizations in East Azerbaijan. $J$ Health 2013;3:20-8.

4. Tagliabue G. The EU legislation on GMOs between nonsense and protectionism an ongoing Schumpeterian chain of public choices. GM Crop Food 2017;8:57-73. doi. 10.1080/21645698.2016.1270488

5. Babazadeh $T$, Nadrian $H$, Mosaferi $M$, Allahverdipour H. Identifying challenges and barriers to participating in the source separation of waste program in Tabriz Northwest of Iran a qualitative study from the citizens perspective. Resources2018;7:53. doi. 10.3390/resources7030053

6. Mohammadi F, Keyvanara M, Samouei R. Awareness and attitude of students and professors of medical sciences universities toward social determinants of health design and preliminary psychometrics of a questionnaire. J Edu Health Prom 2020;9:21-7. doi.10.4103/jehp.jehp_776_19

7. Dorry F, Noorshargh J, Shams A. The status and validity of the independence of arbitration condition in iranian law and international commercial arbitration law regarding the uncitra arbitration in education. Iranian J Comp Edu 2020;3:655-70. doi 10.22034/IJCE.2020.229018.1139

8. Damari B, Vosoogh Moghaddam A, Salarianzadeh H. 3 years performances of the provincial health and food security councils in iran the way forward. J Sch Publ Health Ins Res 2012;10:21-8.

9. Vass C, Rigby D, Payne K. The role of qualitative research methods in discrete choice experiments: a systematic review and survey of authors. Med Dec Mak2017;37:298-313. doi.10.1177/0272989X1 6683934

10. Anwari Z, Shukla M, Maseed BA, Wardak GFM, Sardar S, Matin J, et al. Implementing people-
بخشى، از طريق منابع قدرت بر سياست گذاران و تصميم گيران در سطوح بالاتر تأثير گذارد و براى رفع موانع و ارائُٔ راه كارهاى مناسب كامهاى اساسى و اصولى بردارد. تشكر و قدردانى

اين مقاله بر گرفته از رسالهُ دكترى با عنوان (انقش و

عملكرد شوراهاى فرابخشى مؤثر بر سلامت در ايران و

تدوين الكوى حمايتطلبانهُ مناسب" است كه با حمايت

دبيرخانهُ شوراى عالى سلامت و امنيت غذايى انجام شد. از

centred health systems governance in 3 provinces and 11 districts of Afghanistan a case study. Confl Health 2015;9:1-16. doi.10.1186/1752-1505-9-2

11. Bagherilankaran K, Khankeh HR, Zarei N, Fararouei M, Saboori Z, Joulaei H. [Toward equity under health system reform; a systematic review]. Shiraz Uni Med Sci J 2017;18:61-6. (Persian) doi.10.5812/semj.57724.

12. Kiani MM, Khanjankhani K, Shirvani M, Ahmadi B. Strengthening the primary health care system in Iran a comprehensive review study. J Sch Publ Health Ins Publ Health Res 2020;18:121-38.

13. Aghamolaei T. Principles of health services. Tehran Andisherafi Publication. 2009;P.84-92.

14. Mosadeghrad AM, Rahimitabar P. Health system governance in Iran a comparative study. Razi J Med Sci2019;26:10-28.

15. Zaboli R, Sanaeinasab H. The challenges and solutions for action of social determinants of health in iran: a qualitative study. Iranian J Health Edu Health Prom 2014;2:5-16.

16. Tahan HM. Essentials of advocacy in case management client advocacy model and case manager advocacy strategies and competencies. Profe Case Manage2016;21:217-32.

17. Vahdaninia $\mathrm{V}$, Vosoogh Moghaddam A. Understanding late logic of health policy making: The transition to governance for health. Health Monit J Iranian Ins Health Sci Res2018;17:631-46.

18. Malekmohammadi HR, Vahdaninia V. The evolution of health policy transition to the governance paradigm for health. Publ Pol2016;2:7394. doi .10.22059/PPOLICY.2016.59232

19. Tatar M, Mollahaliloglu S, Şahin B, Aydın S, Maresso A, Hernandez C, et al. Turkey Health System Review. Health Syst Transit 2011;13:1186 doi.10.iris/handle/10665/330325

20. Damari B, Heidari A. [Implementation of integrated management of non communicable disease prevention and control in Iran proposal]. Payesh Health Monit2020;19:7-17.(Persian)

21. Damari B, Vosooghmoghaddam A. Improving approaches of intersectoral collaboration for health by health and food security high council in Iran. J Sch Publ Health Ins Res 2014;11:1-16.

22. Jones B. Determinants of effective collaboration between health care organizations. Lit Rev Veg 
East CentHealth2008;24:50-7.

23. Shokouh SMH, Mohammad A, Emamgholipour S, Rashidian A, Montazeri A, Zaboli R. Conceptual models of social determinants of health a narrative review. Iranian J Publ Health 2017;46:435.

24. World health organization. The Ottawa charter for health promotion $1^{\text {th }}$ ed. Int Con Health Prom Ottawa1986;2: 1-100.

25. Zarei Z, Hessam S, Vahdat S, Oliaeimanesh A. Analysis of the situation and challenges of strategic purchasing in order to achieve universal health coverage in Iran. Qom Uni Med Sci J2020;14:19-30.

26. Pourahmad A, Lotfi S, Omranzadeh B, Mahdi A.
The failure of the integrated urban management in Iran: an analysis from the perspective of interactive and legal problems between the state and municipality. Int J Manage Sci2015;2:1-12.

27. Sahranavard B, Hajhosseini R. The Islamic vigilantism: Dimensional changes on international power and Iranian Islamic Republic prophecy. Int J Adv Stud Hum Soc Sci2019;8:332-49. doi. 10.33945/sami/ijashss.2019.4.3

28. Danaher A. Reducing health inequities enablers and barriers to inter sectoral collaboration. Toronto Welles Ins 2011;2:20. 